Preprints of the

Max Planck Institute for

Research on Collective Goods

Bonn 2008/16

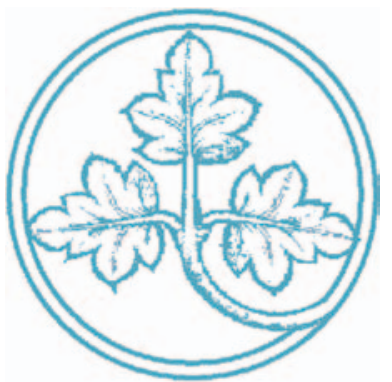

The Principle of

Democratic Teleology in International Law

Niels Petersen

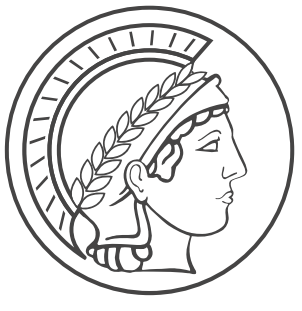




\section{The Principle of Democratic Teleology in International Law}

Niels Petersen

April 2008 


\title{
The Principle of Democratic Teleology in International Law
}

\author{
By Niels Petersen*
}

\begin{abstract}
In the early 1990s, after the fall of the Berlin wall, legal scholars initiated a debate on the existence of a right to democratic governance in international law. Many of the adherents to the democratic entitlement school seem to assume that democratization is a simple shift in the political status, a change from one form of government to another. This contribution seeks to analyze this underlying assumption by taking a look at the current discussion on democratization theory in the political sciences. Through this lens, it will reconsider the international practice and the corresponding legal documents related to the existence of a possible democracy principle. In this respect, a special emphasis will be put on three areas of potential precedents - resolutions of the UN General Assembly, the practice of regional organizations such as the Organization of American States or the African Union, and military interventions in the name of democracy. The analysis will show that the legitimacy principle of international law is, at the same time, more modest and more demanding than the claim of the democratic entitlement school. It will be argued that democracy is no strict obligation, but rather a teleological principle. States are obliged to develop towards democracy and to consolidate and to optimize democracy, once electoral institutions have been established.
\end{abstract}

Senior Research Fellow at the Max Planck Institute for Research on Collective Goods, Bonn. This paper is an extract of my Ph.D. thesis. The main idea was elaborated during my time as Visiting Doctoral Researcher at the Institute for International Law and Justice at the NYU School of Law. I am very grateful to Sergio Dellavalle, Thomas Franck, Matthias Goldmann, Stefan Kadelbach, Benedict Kingsbury, Thomas Kleinlein, Mattias Kumm, Ingo Venzke and Joseph Weiler as well as the members of the J.S.D. Forum of the NYU School of Law for valuable comments and stimulating discussions. 


\section{Contents}

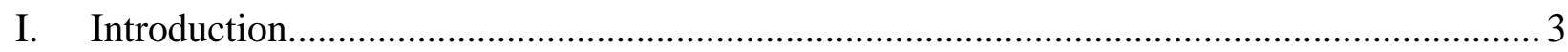

II. Theoretical Framework: Democracy and Democratization................................................ 4

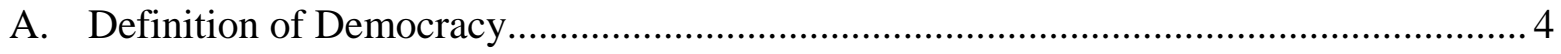

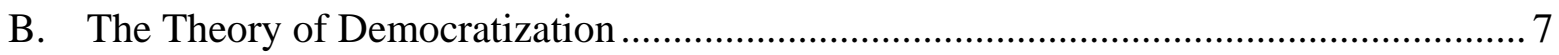

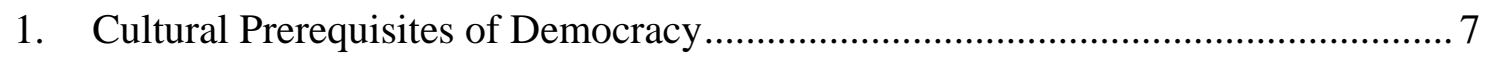

2. Modernization Theory and the Socio-Economic Requisites of Democracy ............ 9

3. Cultural and Ethnic Homogeneity ................................................................. 11

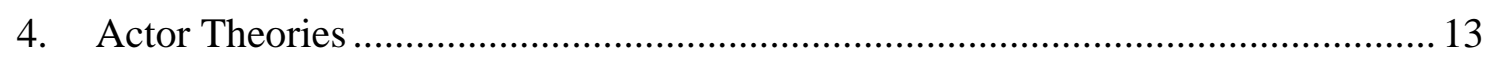

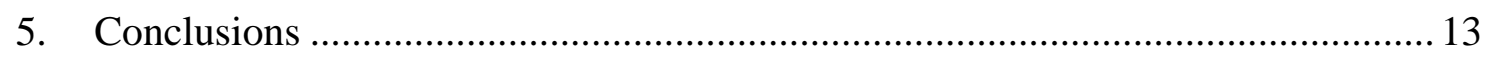

III. Democracy in Positive International Law .................................................................... 14

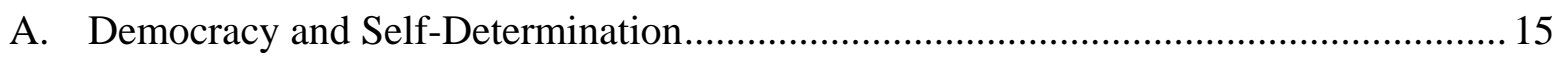

1. Democracy as Mandatory Consequence of Self-Determination ............................ 16

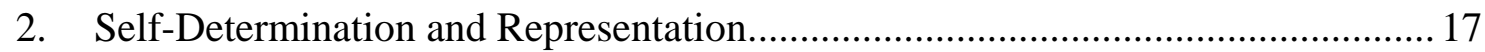

B. The International Practice: Democratic Teleology ........................................................ 18

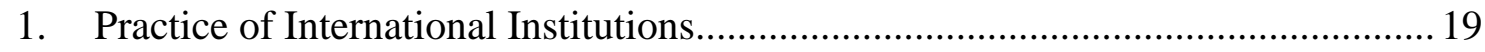

(a) Right to Democratic Elections: CCPR and UDHR...................................... 19

(b) Declarations of the U.N. General Assembly................................................ 21

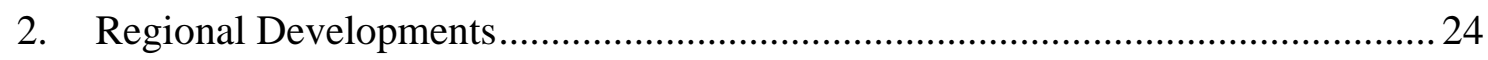

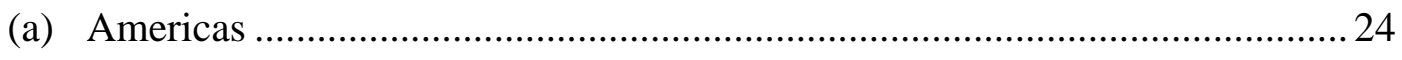

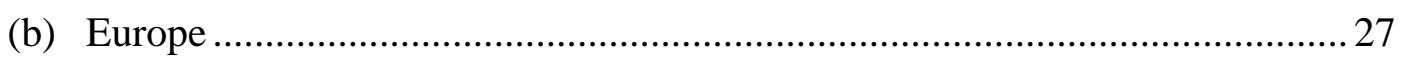

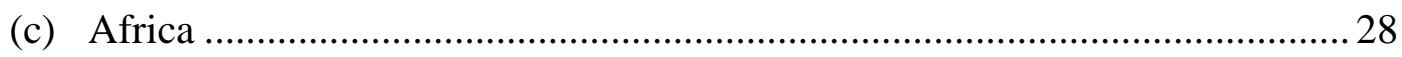

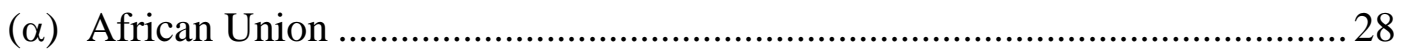

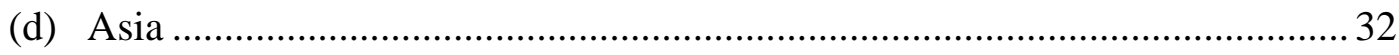

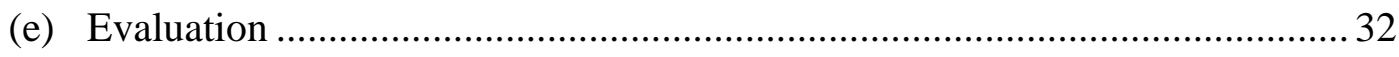

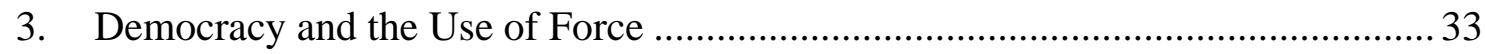

(a) Unilateral Interventions in Grenada, Panama and Iraq .................................. 33

(b) Collective Interventions in Haiti and Sierra Leone....................................... 35

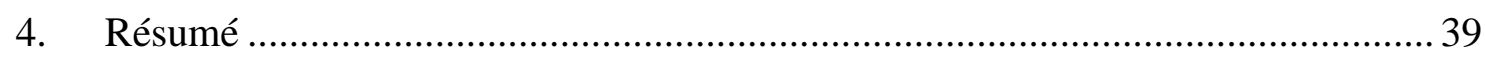

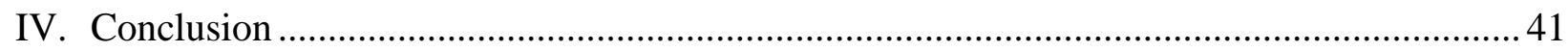




\section{Introduction}

Democracy has for a long time been a non-issue in international law. In 1986, the International Court of Justice declared:

However the régime in Nicaragua be defined, adherence by a State to any particular doctrine does not constitute a violation of customary international law; to hold otherwise would make nonsense of the fundamental principle of State sovereignty, on which the whole of international law rests, and the freedom of choice of the political, social and cultural system of a State. ${ }^{1}$

This changed dramatically in the 1990ies, after the end of the ideological dichotomy of the Cold War. The new interventionism of the UN Security Council and a large number of newly emerging democracies in Latin America, Asia and Africa led to a widespread euphoria about democracy. Francis Fukuyama predicted the end of history, ${ }^{2}$ and legal scholars started to discuss the emergence of a right to democratic governance. ${ }^{3}$ The first major international document addressing this issue was the Vienna Declaration of the World Conference on Human Rights, which recognized that "[d]emocracy, development and respect for human rights and fundamental freedoms are interdependent and mutually reinforcing."

The linguistic connection of democracy and development already shows that the right to democratic governance is not primarily concerned with the industrialized countries of Western Europe and North America. Its principal addressees are developing countries. Democracy differs, however, from traditional human rights in important aspects. While the latter impose either positive or negative obligations on governments and public officials, electoral democracy is addressed to the whole society. Furthermore, the Vienna Declaration does not only independently promote democracy as form of government, but also emphasizes the beneficial influence of democracy on development. This statement turns traditional assumptions of modernization theory, which see economic development as a prerequisite of democratization, ${ }^{5}$ on its head. Democracy is thus promoted as a universal cure for the fight against poverty. It is assumed that it can be instituted at almost any stage in the developmental process and in any society. ${ }^{6}$ This contribution seeks to analyze these underlying assumptions. It tries to reconsider the democratic entitlement thesis through the lens of democratization theory and attempts to redefine the claim by making a more modest proposal.

The analysis will commence with the development of an analytical framework. I will clarify the definition of democracy and then analyze the principal approaches conceptualizing democratiza-

1 Military and Paramilitary Activities in and against Nicaragua (Nicar. v. U.S.), 1986 I.C.J. 14, at para. 263 (June 27).

2 FRANCIS FUKUYAMA, THE END OF HISTORY AND THE LAST MAN (1992).

3 Groundbreaking: Thomas M. Franck, The Emerging Right to Democratic Governance, 86 AM. J. INT'L L. 46 (1992); Gregory H. Fox, The Right to Political Participation in International Law, 17 YALE J. InT'L L. 539 (1992).

4 Vienna Declaration and Programme of Action, ๆ 8, U.N. Doc. A/CONF.157/23 (July 12, 1993).

5 See infra Part II.B.2 for an account of modernization theory.

6 Adrian Leftwich, Governance, democracy and development in the Third World, 14 THIRD WorLD QuARTERLY 605, 605 (1993). 
tion processes (II.). The second part will deal with the debate on the democratic entitlement. I will discuss the existing approaches to this topic and propose a more differentiated approach (III.).

\section{Theoretical Framework: Democracy and Democratization}

In this section, the theoretical foundations of democracy in international law shall be analyzed. I will first define the notion of democracy which shall be the basis of this contribution (A.). In a second step, I will analyze the potential economic, cultural and social preconditions of democ$\operatorname{racy}(\mathrm{B}$.$) .$

\section{A. Definition of Democracy}

Democracy is a contested concept. Although the democratic idea seems to be non-negotiable at least in the Western hemisphere, ${ }^{7}$ there is no consensus on what democracy actually means. ${ }^{8}$ Different scholars fill the concept with different content. Some people propose rather thin or minimalist models of democracy, ${ }^{9}$ while others advocate thick or demanding conceptions. ${ }^{10}$ The search for a definition of democracy is complicated by the fact that there is disagreement on whether democracy is a question of kind or one of degree. ${ }^{11}$ The former concept is a binary one. A political system can either be or not be a democracy. The latter, in contrast, is gradual. Democracy is not an either-or-question, but one of degree, of more or less. Both concepts are, however, complementary, not mutually exclusive. Even to conceive democracy in a gradual way presupposes that we have made an anterior classification. ${ }^{12}$ For it would deprive the concept of every heuristic value to qualify authoritarian or totalitarian regimes as a democracy to a certain degree. Once we have made a binary classification, it may, however, be valuable to distinguish different types of democracy on a gradual scale, as long as we do not perceive democracy solely to be an ideal concept. The notion of democracy thus has two dimensions: on the one hand, a binary classification, a distinction between democracies and non-democracies, and, on the other hand, a graduation, which distinguishes democracies of different quality.

Turning to the binary dimension, there are two ways to address the issue of defining the concept. On the one hand, we can look at whether the relevant sources either explicitly or implicitly pro-

7 IAN SHAPIRO, THE STATE OF DEMOCRATIC THEORY 1 (2006).

8 LAURENCE WHITEHEAD, DEMOCRATIZATION: THEORY AND EXPERIENCE 14 (2002).

9 See, e.g., Adam Przeworski, Minimalist conception of democracy: a defense, in DEMOCRACY'S VALUE 23 (Ian Shapiro \& Casiano Hacker-Cordón eds., 1999).

10 See MiCHAEL WALZER, Thick And Thin. Moral Argument At Home And Abroad 21-39 (1994); Susan Marks, Human Rights, Democracy and Ideology, 8 ColleCTED CourSES OF THE ACEDEMY OF EUROPEAN LAW 51 (1997).

11 GIOVANNI SARTORI, THE THEORY OF DEMOCRACY REVISITED 183 (1987).

12 Id. at 184-85; Armin von Bogdandy, Demokratisch, demokratischer, am demokratischsten? Zur Steigerungsfähigkeit eines Verfassungsprinzips am Beispiel einer Neugestaltung der Verordnungsgebung, in VERFASSUNG - PhILOSOPHIE - KIRCHE. FESTSCHRIFT FÜR AlEXANDER HOLLERBACH ZUM 70. GEBURTSTAG 364, 367 (Joachim Bohnert et al. eds., 2001). 
vide a definition of democracy. On the other hand, we can also establish a proper definition of democracy and analyze whether such a concept exists in international law, notwithstanding whether it is actually called democracy. At first glance, it seems tempting to go the first way. Such an analysis is, however, deceptive. The term 'democracy' is used very rarely in international legal documents - perhaps precisely because of its vagueness. Where it can be found, its meaning is not further specified. ${ }^{13}$ The aforementioned Vienna Declaration ${ }^{14}$ or the Agenda for Peace of the UN Secretary General ${ }^{15}$ only allude to the positive effects of democracy on human rights, development and peace. Savings clauses of international human rights instruments like to recur to the notion of democratic society, ${ }^{16}$ without defining the meaning of this term.

There is, however, one prominent exception: in 2000, the UN General Assembly adopted a resolution under the title "Promoting and Consolidating Democracy"17 according to which democracy consists of a number of different elements: the promotion of pluralism, the protection of human rights, the separation of powers, the rule of law, elections, the development of a civil society, good governance, sustainable development, solidarity, and social cohesion. This definition, however, appears to be more of a wish list, a conglomeration of desirable ideas and institutions, than the attempt to propose a coherent conception of democracy. On the one hand, it mingles substantive and procedural issues without saying anything about their interrelation; on the other, it does not distinguish between the rule of the political game, the institutional framework of government, and certain programmatic issues, ${ }^{18}$ such as social cohesion and sustainable development.

If we turn to the political science literature, we find a number of different definitions of democracy. Some are minimalist, concentrating on elections. ${ }^{19}$ Other scholars add elements such as the rule of law ${ }^{20}$ or the guarantee of certain political rights to their definition. In his influential contribution on political polyarchies, Robert Dahl also includes other institutions in his definition: certain political human rights, like freedom of expression, information and association, as well as

13 But cf. also Steven WheAtley, Democracy, MinORities AND InTERnATIONAL LAW 128-34 (2005) (noting that democracy is defined by international legal documents as a political system in which power is based on the will of the people). However, the concept of the will of the people is not less abstract than that of democracy so that this kind of definition is not of much help in specifying the latter.

14 Vienna Declaration, supra note 4.

15 An Agenda for Peace, Preventive Diplomacy, peacemaking and peace-keeping, report of the Secretary General, U.N. Doc. A/47/277-S/24111 (June 17, 1992).

16 See International Covenant on Civil and Political Rights art. 14 (1), 21, 22 (2), Dec. 19, 1966, 999 U.N.T.S. 171; Convention for the Protection of Human Rights and Fundamental Freedoms art. 6 (1), 8 (2), 9 (2), 10 (2), 11 (2), Nov. 4, 1950, 213 U.N.T.S. 222; American Convention on Human Rights art. 15, 16 (2), 22 (3), 32 (2), Nov. 22, 1969, 1144 U.N.T.S. 123.

17 G.A. Res. 55/96, U.N. Doc. A/RES/55/96 (Dec. 4, 2000).

18 See SARTORI, supra note 11, at 90 (explaining this distinction).

19 Przeworski, supra note 9.

20 See, e.g., Armin von Bogdandy, Globalization and Europe: How to Square Democracy, Globalization, and International Law, 15 EUR. J. INT’L L. 885, 889 (2004). 
an inclusive status of citizenship. ${ }^{21}$ Other scholars add even further human rights or institutions, such as the protection of minorities ${ }^{22}$ or social rights ${ }^{23}$.

Defining democracy is such a difficult issue because often the debates on what democracy is and on what democracy should be are intermingled. Most scholars advocating a thick concept of democracy that goes beyond the mere legitimation of governance through elections take an idealist position and include their idea of what a political system should look like in their conception of democracy. One ideal democracy concept will, however, not be detectable in international law because of the great number of different traditions and cultures which shape and are part of the international order. For this reason, I would like to choose a different way. As democracy is highly contested and malleable at its borders, ${ }^{24}$ this analysis shall concentrate on the core, the legitimation of public power through elections. A political system may be called a democracy, when its government is designated in periodic and contested elections. ${ }^{25}$ Elections are contested when their outcome is uncertain ex ante and irreversible ex post. ${ }^{26}$

This definition is meant to be purely descriptive and does not contain a normative argument. It does not exclude that there are good reasons for other, more demanding concepts of democracy. However, the protection of human rights or the implementation of the rule of law are separate institutions which can be distinguished from the establishment of democracy and subject to independent analyses. ${ }^{27}$ It is possible to imagine an autocratic regime observing the rule of law or complying with human rights obligations. An autocracy in which the government is appointed through contested elections is, however, a contradictio in adjecto.

As mentioned, democracy has also a second dimension. Recently, Susan Marks has cautioned against adopting a minimalist concept of democracy in the realm of international law. ${ }^{28}$ Concurrently, there is a tendency in international relations to idealize democracy. In this context, it may be dangerous to promote undemanding democracy concepts as legal standards. For, if states have reached this minimum threshold, they are immune against further critique. Marks thus proposes to employ a gradual concept of democracy. ${ }^{29}$ But gradual conceptions are, as I have pointed out earlier, only a complement, no substitute to classificatory conceptualizations. The critique shall thus be addressed not by substituting our binary definition, but by adding a second, gradual dimension to our conception of democracy.

ROBERT ALAN DAHL, POLYARCHY: PARTICIPATION AND OPPOSITION 3 (1971).

22 Steven Wheatley, Democracy in International Law: A European Perspective, 51 InT'L \& CoMP. L. Q. 225 (2002).

23 DAVID BEETHAM, DEMOCRACY AND HuMAN RighTS (1999).

24 WHITEHEAD, supra note 8, at 15.

25 See ADAM PRZEWORSKI ET AL., DEMOCRACY AND DEVELOPMENT: PoliticAl InSTITUTIONS AND WELLBEING IN THE WORLD, 1950-1990 at 14-18 (2000) (proposing this definition).

26 Id. at 16.

27 Manfred G. Schmidt, Ist die Demokratie wirklich die beste Staatsverfassung?, 28 ÖsTERREICHISCHE ZEITSCHRIFT FÜR POLITIKWISSENSCHAFT 187, 191-92 (1999).

28 Susan Marks, The "Emerging Norm": Conceptualizing "Democratic Governance", 91 ASIL PROCEEDINGS 372-76 (1997); Marks, supra note 10, at 78-88.

Id. at 81-82. 


\section{B. The Theory of Democratization}

The transition from an authoritarian regime to a democratic system is not only a simple shift in political status, but a social process which is influenced by different external factors. When the debate on democratization started in the late 1950s, it addressed the issue by analyzing the 'prerequisites of democracy'. ${ }^{30}$ In its strict sense, the term suggests that democracy has certain necessary requirements, without which democracy is not able to function. Still today, there are authors who promote such a strict approach and argue that certain cultural environments are hostile to democracy (a.). The majority of scholars, however, pursue a more moderate approach. They try to identify socio-economic factors which may be favorable to the establishment of democracy. The earliest and most influential school is the so-called modernization theory, which tries to establish a correlation between economic development and democracy (b.). Further scholars inquire into the relationship of ethnic, social or religious homogeneity and the prospects for democracy (c.). While the three approaches mentioned so far are concerned with the social environment of democratization on the macro level, a further school instead concentrates on the micro-processes of democratization. Its adherents analyze the behavior of political elites in transition processes (d.).

\section{Cultural Prerequisites of Democracy}

The theory of democracy's cultural prerequisites argues that the establishment of democracy depends on the cultural environment of the respective state. Most prominently, this was put forward by Samuel Huntington, who divides the world into eight major civilizations: the Western, the Confucian, the Japanese, the Islamic, the Buddhist, the Orthodox, the Latin American, and the African Cultures. ${ }^{31}$ Among these, only the Western, the Latin American and the Japanese culture are regarded as favorable to democracy. Three further civilizations are supposed to be neutral with regard to democracy, while Islam and Confucianism are conceived as hostile to democracy. ${ }^{32}$ On first glance, there is some empirical evidence for Huntington's thesis. Among the about thirty highly-developed states having a per capita income of more than 20,000 USD, ${ }^{33}$ only states coming from one of the two cultural environments classified by Huntington as hostile to democracy are not qualified as electoral democracies by the Freedom House's Survey of Civil and Political Rights. ${ }^{34}$ These states are Brunei Darussalam, Hong Kong, Kuwait, Qatar, Singapore, and the United Arab Emirates.

30 Seminally Seymour Martin Lipset, Some Social Requisits of Democracy: Economic Development and Political Legitimacy, 53 Am. PoL. Sc. ReV. 69 (1959).

31 Samuel P. Huntington, The Clash of Civilizations?, 72 ForeIGN AfF. 22, 25 (1993).

32 SAMUEL P. hUNTINGTON, The Third Wave: Democratization in the Late Twentieth Century 300 (1991).

33 GDP data for 2004: IMF, World Economic Outlook Database, April 2007, http://www.imf.org/external/pubs/ft/weo/2007/01/data/index.aspx.

34 Freedom House's Annual Global Survey of Political Rights and Civil Liberties (2007), http://www.freedomhouse.org/uploads/press_release/fiw07_charts.pdf. 
Nevertheless, Huntington's analysis is not convincing. There is some empirical evidence against the thesis that Islam or Confucianism are per se hostile to democracy. Japan, Taiwan or South Korea, states which are molded by Confucianism, can be qualified as electoral democracies. Equally, Indonesia, the country with the largest Muslim population can be considered as an electoral democracy. Although certain religious or cultural values, such as the lack of separation between the religious and the political sphere, may be an obstacle to the establishment of a democratic society, this is no particularity of Islam or Confucianism, but rather an expression of socioeconomic progression. ${ }^{35}$ Religious or cultural patterns are subject to change in the course of social development. ${ }^{36}$ In this context, a short glance into the academic past might be illuminating: In the middle of the 20th century, Catholic societies had been qualified by a number of political scientists as hostile to democracy. ${ }^{37}$ However, many states with a predominantly Catholic population have meanwhile developed into stable democracies. It thus seems that culture is no determinant factor in the process of democratization. Impediments which have been attributed to culture often have other reasons. Therefore, culture is no absolute obstacle to democracy, but at most a surmountable difficulty in the process of democratization.

However, the question of the cultural prerequisites of democracy is not purely empirical. It also has a normative dimension. Culture and democracy are interdependent. Thus, if the preconditions for democratization are to be established in a certain society, this leads to a necessary change of its culture. From a normative perspective, such a development is not without problems. In order to illustrate the point, Michael Walzer once introduced a hypothetical example into the discussion. Algerian fundamentalists establish a repressive military dictatorship and a 'religious republic' without individual liberties. ${ }^{38}$ Walzer assumes that this régime is deeply rooted in the political and religious culture of Algeria. In this hypothetical situation, the Swedish government allegedly has a chemical weapon which allows the transformation of every Algerian into a Swedish social democrat. Walzer argues that it is morally prohibited to use this weapon because we would then impose our political and cultural values on an Algerian people which has a fundamentally different system of values. ${ }^{39}$

This question does not only concern the Islamic region. In the 1990s, some Asian governmental leaders, such as Malaysia's Prime Minister Mahathir bin Mohamad and Singapore's Head of State Lee Kuan Yew initiated a debate on Asian values. They argued that Western democracy could not simply be imposed on Asian societies because they were not compatible with certain Asian traditions. Asian societies tend to perceive political communities as a system of obliga-

35 Pippa Norris \& Ronald Inglehart, Islamic Culture and Democracy: Testing the 'Clash of Civilizations' Thesis, 1 COMPARATIVE SOCIOLOGY 235, 239-41 (2002).

36 WOLFGANG MERKEL \& HANS-JÜRGEN PUHLE, Von DER DikTATUR Zur DEMOKRATIE: TrANSFORMATIONEN, ERFOLGSBEDINGUNGEN, ENTWICKLUNGSPFADE 40 (1999); Seymour Martin Lipset, The social prerequisites of democracy revisited, 59 AM. SoC. REV. 1, 7 (1994).

37 Cf., e.g., Pierre Elliott Trudeau, Some Obstacles to Democracy in Quebec, in CANADIAN DuALISM 241, 245 (Mason Wade \& Jean-Charles Falardeau eds., 1960); Kenneth A. Bollen, Political Democracy and the Timing of Development, 44 AM. Soc. REV. 572, 584 (1979).

38 Michael Walzer, The Moral Standing of States: A Response to Four Critics, 9.3 PHIL. \& PuBL. AfF. 209,225 (1980).

39 Id. at 226. 
tions rather than a system of rights, and their values are rather community-oriented. ${ }^{40}$ There may be two different motivations behind this argument. The first one is of strategic nature. Brought forward by politicians, who are beneficiaries of the status quo and who claim the authority to define what Asian values are, the argument merely has an apologetic function. ${ }^{41}$

If it is not only supposed to justify a certain government, it has a functional rather than a normative character. ${ }^{42}$ The main purpose is to stress collective values. However, if we understand democracy as a procedural framework, then the concept has sufficient flexibility in order to realize different values and hierarchies of values. Cultural relativism has no answer to too many questions: Who defines the cultural tradition of a certain people? Who determines the composition of the group whose cultural tradition shall be relevant? With regard to the latter question, it is not imperative to take the collectivity of the citizens as the point of reference because the population can be very heterogeneous. ${ }^{43}$ Against this background, we can see that Walzer's parable is exaggerated. It is, of course, not justified to transform Algerian fundamentalists into Swedish 'social' democrats. However, this does not discredit the promotion of democratic rules in general.

\section{Modernization Theory and the Socio-Economic Requisites of Democracy}

Modernization theory seeks to establish a relationship between the development of a state and its degree of democratization. ${ }^{44}$ The work of Martin Seymour Lipset, who claimed in 1959 that "the more well-to-do a nation, the greater the chances that it will sustain democracy" 45 , was groundbreaking. For this relationship, Lipset offers several reasons. In particular, economic development leads to a higher level of urbanization ${ }^{46}$ and education ${ }^{47}$. Furthermore, economic prosperity causes the establishment of a middle class and an increased vertical mobility and permeability among classes. Both deprive the underclass of its revolutionary potential and thus support the stability of the democratic system. ${ }^{48}$ Finally, political elites have to fear less disadvantages in case of a change of government, because the relative effect of a policy change is stronger in poor than in rich countries. ${ }^{49}$

Since the publication of Lipset's theory, several empirical studies have confirmed a correlation between economic development and democratization: a higher economic prosperity increases the

40 Diane Mauzy, The Human Rights and 'Asian Values' Debate in Southeast Asia: Trying to Clarify the Key Issues, 10 PACIFIC REV. 210, 215 (1997).

41 WOLFGANG MERKEL, Demokratie in Asien. Ein Kontinent Zwischen DikTatur Und Demokratie 91 (2003).

42 Jürgen Habermas, Zur Legitimation durch Menschenrechte, in DiE POSTNATIONALE KonSTELLATION 170, 186 (1998).

43 Ronald Dworkin, Liberal Community, 77 CAL. L. REV. 479, 488-89 (1989).

44 See the seminal work by Lipset, supra note 30; IDEM, POLITICAL MAN. THE Social BASES OF Politics 45-76 (1960). See also DANIEL LERNER, The PAssing of Traditional Society. Modernizing The MidDLE EAST 63-64 (1958).

45 Lipset, supra note 30, at 75.

$46 \quad$ Id. at 78.

47 Id. at 78-82; Seymour Martin Lipset, Kyoung-Ryung Seong \& John Charles Torres, A comparative analysis of the social requisites of democracy, 45 INT’L SOC. SCI. J. 155, 167 (1993).

$48 \quad$ Lipset, supra note 30, at 83.

$49 \quad I d$. at 84. 
probability that a state has a stable democratic system. ${ }^{50}$ However, there is no causal relationship between both factors. ${ }^{51}$ Economic development is neither a necessary nor a sufficient precondition for democracy. There are important exceptions which disprove a determinist relationship. India, for example, has been a relatively stable democracy for several decades, although the GDP per capita is below 1,000 USD. On the other hand, several Arab states have not yet developed democratic structures, notwithstanding a high per capita income.

Furthermore, empirical data suggests that economic development does not primarily influence the transition to democracy. Economic prosperity rather stabilizes democratic institutions once they have developed. ${ }^{52}$ In particular, poor democracies face a high probability of collapsing. ${ }^{53}$ Only after having reached a certain stage of development are democracies sufficiently stable to survive economic crises. However, economic development is not the only factor that influences the democratization process.

All political systems know informal rules and arrangements in their political process. ${ }^{54}$ Such mechanisms may ideally complement the formal constitutional institutions and increase their flexibility. However, if the democratic system is unstable or defective, such informal networks are often used to pervert the democratic rules. ${ }^{55}$ The political actors try to strengthen their power by relying on particularistic networks outside of the constitutional institutions. Such defective democracies are thus likely to break down in social or economic crises or to transform into open autocracies.

How do defective democracies differ from functioning ones? An approach elaborated by Tatu Vanhanen takes a rationalistic standpoint and establishes a relationship between the degree of democratization and the dispersion of social power resources. ${ }^{56}$ If power resources are widely dispersed, it is difficult for a specific group of society to suppress other social groups and to establish or maintain hegemonic structures. ${ }^{57}$ The degree of dispersion is related to other socio-

50 PHILIP COULTER, Social Mobilization And LiBeral Democracy (1975); Kenneth A. Bollen \& Robert W. Jackman, Economic and Noneconomic Determinants of Political Democracy in the 1960s, 1 RES. POL. Soc. 27, 42 (1985); Larry Diamond, Economic Development and Democracy Reconsidered, in REEXAMINING Democracy. EsSAYS IN HonOR OF SEYMOUR MARTIN LipSET 93 (Gary Marks \& Larry Diamond eds., 1992); Lipset, Seong \& Torres, supra note 47.

51 DAHL, supra note 21, at 71; ZEHRA F. ARAT, DEMOCRACY AND HuMAN RightS IN DEVELOPING COUNTRIES 33 (1991); MERKEL \& PUHLE, supra note 36, at 33; PRZEWORSKI ET AL., supra note 25, at 88; MANFRED G. SCHMIDT, DEMOKRATIETHEORIEN 441 (3rd ed. 2000); Bruce J. Bueno de Mesquita \& George W. Downs, Development and Democracy, 84 Foreign AfF. 77 (2005).

52 Adam Przeworski \& Fernando Limongi, Modernization: Theories and Facts, 49 WoRLD PoLITICS 155 (1997).

$53 \quad$ Id. at 170.

54 Wolfgang Merkel \& Aurel Croissant, Formale und informale Institutionen in defekten Demokratien, 41 PoLITISCHE VIERTELJAHRESSCHRIFT 3, 16 (2000); CHARLES TILLY, DEMOCRACY 88 (2007).

55 WOLFGANG MERKEL ET AL., DEFEKTE DEMOKRATIE 28 (2003).

56 TATU VANHANEN, The Process of DeMOCRATIZATION (1990); idem, Social Constraints of Democratization, in Strategies of Democratization 19 (1992); IDEM, Prospects of Democracy (1997). Id. at 24. 
economic factors, such as economic development and level of education. ${ }^{58}$ Vanhanens's approach is thus a supplement rather than a contrast to modernization theory.

Another explanation has been offered by Charles Tilly, who argues that state capacity is the decisive factor for a successful democratization process. ${ }^{59}$ Strong institutions increase the prospects of success. In contrast, the emergence of autonomous power centers is one of the biggest obstacles. $^{60}$ Of course, there are limits: if the state is too strong, political actors have incentives to claim exclusive power and to undermine democratization. Thus, informal 'trust networks' have to be integrated into the public political space. ${ }^{61}$ Power dispersion thus continues to have an important function. However, it has to take place within state institutions and shall not be in opposition to them.

Turning to cultural scholarship, we find that democracy depends on the internalization of democratic values by citizens and political elites. ${ }^{62}$ Certainly, the embrace of democratic values does not happen over night. They rather have to be learned, internalized and accumulated as social capital. $^{63}$ They require experience with democratic institutions and a corresponding education. ${ }^{64}$ Furthermore, socio-economic change may lead to a transformation of political values. ${ }^{65}$

Summarizing these findings, we can draw the following conclusions: the functioning and stability of democracy depend on several different factors - a democratic culture, socio-economic development, stable institutions, the integration of trust networks into the public political space and the dispersion of power resources. These factors are interdependent. Democratization does thus not only depend on sound institutional design. It is rather rarely an abrupt transition, but subject to a gradual process. ${ }^{66}$

\section{Cultural and Ethnic Homogeneity}

The debate on cultural, religious and ethnic homogeneity as a precondition for a stable democracy dates back to John Stuart Mill, according to whom

$58 \quad$ Id. at 25.

59 TILLY, supra note 54, at 161-85.

$60 \quad$ Id. at 164.

$61 \quad$ Id. at 80-105.

62 GABRIEL ABRAHAM ALMOND \& SIDNEY VERBA, THE CiVIC CULTURE: POLITICAL ATTITUDES AND Democracy in Five Nations 498 (1963); Larry Diamond \& Juan José Linz, Politics, Society, and Democracy in Latin America, in Democracy in Developing Countries: LATin America 1, 10 (Larry Diamond, Juan José Linz \& Seymour Martin Lipset eds., 1989).

63 ROBERT D. PUTNAM, MAKING DEMOCRACy WORK: CiVic TRADiTIONS IN MOdERn ITALy 99-116 (1993).

64 ALMOND \& VERBA, supra note 62, at 501. In this context, it is interesting to note that former British colonies have far more success with the installation of democracy than their French, Belgian, Dutch, Spanish or Portuguese counterparts. See Bollen \& Jackman, supra note 50; Myron Weiner, Empirical Democratic Theory, in Competitive Elections in Developing Countries 3, 19 (Myron Weiner \& Ergun Özbudun eds., 1987). See also Lipset, supra note 36, at 5 (noting that this is probably due to the fact that the British - in contrast to other colonial powers - introduced certain democratic institutions in their colonies).

65 Diamond \& Linz, supra note 62, at 12.

66 Lipset, supra note 36, at 4. 
[f]ree institutions are next to impossible in a country made up of different nationalities. Among a people without fellow-feeling, especially if they read and speak different languages, the united public opinion, necessary to the working of representative government, cannot exist. ${ }^{67}$

In many plural societies where identity is heavily influenced by the belonging to a single cultural, ethnic or religious group, voting often follows social affiliations. ${ }^{68}$ It is thus barely surprising that empirical studies suggest that the probability to establish democracy in an ethnically homogeneous society is twice as high as in a segmented society. ${ }^{69}$

Different authors have proposed remedies to overcome the problem of segmentation. The most widely recognized proposal is Martin Lijphart's model of consociational democracy. ${ }^{70}$ Lijphart proposes to establish a system in which every major social group is represented. He identifies four fundamental characteristics: government by a grand coalition, mutual veto rights in order to protect minority interests, proportional representation in politics and civil service, as well as a proportional allocation of public funds, and a federal structure giving each segment a high amount of autonomy. ${ }^{71}$

However, consociationalism implicitly assumes that human identity is unalterable. Yet, identities are no natural characteristic of human beings, but social constructs. ${ }^{72}$ They can evolve and change with time and circumstance although not being infinitely malleable. ${ }^{73}$ Research in social psychology shows that the interaction between different social groups can be enhanced if it is possible to establish a common superordinate identity. ${ }^{74}$ Consociationalist models thus run the risk of deepening rather than overcoming segmentations in society. This does not mean that democracy is not possible in plural societies. The solution should instead be to establish voting procedures which discourage incentives to vote according to ethnic or religious cleavages. ${ }^{75}$ Such procedures may prescribe that parties have to rely on votes of more than one social group in order to be elected, which could, for example, be managed by the introduction of certain minimum quota.

But even the latter form of democratization bears certain risks. Without a consensus about the fundamental rules of the political game, incentive-based voting mechanisms cannot surmount social cleavages. ${ }^{76}$ The recipe in these cases resembles the approaches to socio-economic devel-

67 JOHN STUART MILL, CONSIDERATIONS ON REPRESENTATIVE GOVERNMENT 230 (1861).

68 Dirk Berg-Schlosser, Empirische Voraussetzungen und allgemeine Konstituierungsbedingungen von Demokratie, in Perspektiven der Demokratie: Probleme und Chancen IM ZeItalter Der Globalisierung 57 (Dirk Berg-Schlosser \& Hans-Joachim Giegel eds., 1999).

69 Adrian Karatnycki, The Decline of Illiberal Democracy, 10.1 J. DEM. 112, 117 (1999).

70 AREND liJPHART, Democracy in Plural Societies (1977); idem, Democracies: Patterns of MaJORITARIAN AND CONSENSUS GOVERNMENT IN TWENTY-ONE COUNTRIES 21-36 (1984).

71 LIJPHART, PLURAL SOCIETIES, supra note 70, at 25.

72 DONALD L. HOROWITZ, ETHNIC GROUPS IN CONFLICT 684 (1985).

73 SHAPIRO, supra note 7, at 95.

74 Samuel L. Gaertner et al., The Common Ingroup Identity Model: Recategorization and the Reduction of Intergroup Bias, 4 EuR. REV. SOCIAL PsyCHOLOGY 1 (1993).

75 See the proposals of HOROWITZ, supra note 72, at 628-52.

76 Andrew Reynolds, Constitutional Medicine, 16 J. DEM. 54, 57 (2005). 
opment. States with highly segmented societies often have a weak institutional structure. ${ }^{77}$ Thus, formal institutions have to be strengthened and trust in these institutions has to be developed. At the same time, it is necessary to establish a common identity. Consequently, nation and capacity building in these cases ideally precedes the transition to democracy. ${ }^{78}$

\section{Actor Theories}

While the approaches presented so far have dealt with the macro-environment of democratization, the actor theories focus on the political actors involved in democratization periods. Under a rational choice perspective, transition to democracy occurs if it is rational for the relevant political elites to establish a democratic system in order to pursue their interests. ${ }^{79}$ This is mostly the case if no political group possesses a clear advantage over its adversaries so that democracy, as institutionalized insecurity about the future policy, ${ }^{80}$ appears to be the best compromise, giving everyone the theoretical opportunity to attain a share of the power. ${ }^{81}$ In the period of democratic consolidation, democracy survives if the government has incentives not to manipulate the outcome of elections and if it hands over its power after losing the elections. ${ }^{82}$ In established democracies, it is an important factor that politicians trust to have the opportunity to regain power in future elections. If such a trust has not yet been established, it is important that the members of the parting government have suitable professional alternatives in order to reduce the costs of losing power - and thus the incentives to keep it against the law - as much as possible. ${ }^{83}$ Socioeconomic development is thus again a decisive aspect of the political game. Further factors influencing the incentive structure of political elites are the internalization of democratic values ${ }^{84}$ and the dispersion of power within society. ${ }^{85}$ The incentives of the political actors are thus dependent on the macro environment.

\section{Conclusions}

The different attempts to explain democratization draw a complex picture. They do not exclude each other mutually, but highlight different aspects in the process of democratization. Transition

77 TILLY, supra note 54, at 176-77.

78 Philippe C. Schmitter \& Javier Santiso, Three Temporal Dimensions to the Consolidation of Democracy, 19 INT'L POL. SC. REV. 69, 81 (1998).

79 Adam Przeworski, Some Problems in the Study of the Transition to Democracy, in Transitions From Authoritarian Rule: Prospects For Democracy. Volume III: Comparative Perspectives 47 (Guillermo O'Donnell, Philippe C. Schmitter \& Laurence Whitehead eds., 1986); ADAM PRZEWORSKI, DEMOCRACY AND THE MARKET (1991); GUILLERMO O'DONNELL \& PHILIPPE C. SCHMITTER, TRANSITIONS FROM Authoritarian Rule: Prospects for Democracy. Volume Iv: Tentative Conclusions About UnCERTAIN DEMOCRACIES (1986); Michael Burton, Richard Gunther \& John Higley, Introduction: elite transformations and democratic regimes, in ELITES AND DEMOCRATIC CONSOLIDATION IN LATIN AMERICA AND SOUTHERN EUROPE 1 (John Higley \& Richard Gunther eds., 1992); GEORG SØRENSEN, DEMOCRACY AND Democratization. PROCESS AND PROSPECTS IN A CHANGING WORLD 28 (1998).

80 Przeworski, Transition to Democracy, supra note 79, at 59.

81 SØRENSEN, supra note 79, at 28.

82 PRZEWORSKI, supra note 79, at 10-34.

83 I owe this idea to Professor Thomas Franck.

84 Burton, Gunther \& Higley, supra note 79, at 30.

85 SHAPIRO, supra note 7, at 90. 
to and consolidation of democracy do not permit monocausal explanations, but depend on a variety of different factors. ${ }^{86}$ They show that democracy has no necessary or sufficient prerequisites - neither a low level of economic development nor a significant ethnic and cultural heterogeneity as such exclude the establishment of a relatively stable democracy. ${ }^{87}$ Nor does economic prosperity lead to an automatic transition to democracy.

However, despite the lack of causal explanations, there are significant correlations. It is likely that low economic development or social heterogeneity endanger the consolidation of democracy. Indeed, these obstacles are malleable. ${ }^{88}$ But they are subject to long-term processes that are not necessarily steady. ${ }^{89}$ Sometimes it may be reasonable to compromise on short-term success in order to pursue long-term goals. ${ }^{90}$ In certain circumstances, it may, furthermore, be advisable to engage in nation- and identity-building before pursuing the establishment of institutions. Because there is no universally valid formula for success, many political scientists stress the process-like character and the unpredictability of democratization. It does not suffice to establish certain institutions, but it is a "complex, long-term, dynamic and open-ended process". ${ }^{91}$ Even if elections have to enter the stage at a certain point, they are not necessarily the first step. ${ }^{92}$ Rather, democratization is a teleological process, ${ }^{93}$ the final objective of which is the establishment of a legitimate form of government, but which does not necessarily have to be democratic itself. ${ }^{94}$

\section{Democracy in Positive International Law}

The legal democratic entitlement school tries to establish a right to democratic governance as part of customary international law. According to the general definition contained in art. 38 (1) lit. b of the ICJ Statute ${ }^{95}$, customary law consists of two elements: state practice and opinio iuris. Customary Norms are thus principally identified by an inductive abstraction from patterns of state behavior. However, there is an important trend in legal scholarship which recognizes an additional way of identifying customary norms, particularly in the Continental literature. Under the premise that the legal system is perceived as a coherent and holistic system without internal contradictions, customary norms may also be justified through deduction. If a certain principle follows necessarily from a more abstract principle which has already been accepted as customary

86 MERKEL \& PUHLE, supra note 36, 62; SHAPIRO, supra note 7, at 80.

87 MAMOUDOU GAZIBO, LES PARADOXEs DE LA DÉMOCRATISATION EN AFRIQUE 228 (2005).

88 Juan José Linz \& Alfred Stephan, Toward Consolidated Democracies, 7.2 J. DEM. 14, 23 (1996).

89 Schmitter \& Santiso, supra note 78, at 82-84; RALF DAHRENDORF, REFLECTIONS ON THE REVOLUTION IN EUROPE 99-100 (2005).

90 Javier Santiso, A la recherche des temporalités de la démocratisation, 44 REVUE FRANÇAISE DE SCIENCES POLITIQUES 1079, 1082 (1994).

91 WHITEHEAD, supra note 8, at 27.

92 Marks, supra note 10, at 87.

93 Andreas Schedler, What is Democratic Consolidation?, 9.2 J. DEM. 91, 95 (1998). When Whitehead emphasizes the open-endedness of the process, he does not want to contest the teleological character of democratization. See WHITEHEAD, supra note 8, at 28 (expressing that democracy is a concept which is, to a certain extent, indeterminate and can be implemented in a variety of different ways).

94 See Schmitter \& Santiso, supra note 78, at 79 on the undemocratic nature of many democratization processes.

95 Statute of the International Court of Justice, June 26, 1945, 30 U.N. Y.B. 1052. 
law, then the former principle has equally to be part of the custom because the legal order would otherwise be contradictory. ${ }^{96}$ With regard to the right to democratic governance, we can find both approaches to justify a customary norm, an inductive and a deductive one. ${ }^{97}$ In the following, I will first turn to the latter. ${ }^{98}$

\section{A. Democracy and Self-Determination}

The deductive approach, which is primarily promoted in European scholarship, tries to deduce a right to democratic governance from the principle of self-determination. ${ }^{99}$ Self-determination had at first a primarily external direction. The principle had its strongest impact in the context of decolonization. ${ }^{100}$ However, by its incorporation into the common art. 1 of the two human rights covenants from $1966^{101}$, it also received an internal dimension. ${ }^{102}$ According to this provision, the right to self-determination attributes to every people, inter alia, the right freely to determine its political status. This internal dimension has been affirmed by the friendly relations declaration of the UN General Assembly ${ }^{103}$, which also underlined the right to determine the own political status.

96 Albert Bleckmann, Völkergewohnheitsrecht trotz widersprüchlicher Praxis? 36 HEIDELBERG J. INT’L L. 374, 390 (1976); Christian Tomuschat, Obligations Arising for States without or against their Will, 241 RECUEIL DES COURS 195, 293-300 (1993).

97 Both approaches are not mutually exclusive. See Franck, supra note 3 (relying on both justifications). Franck calls his approach "inductive" (at 51), but also recurs to the principle of self-determination (at 52-63).

98 This distinction is, of course, a simplification. There are also other approaches dealing with democracy in international law. See, e.g., SUSAN MARKS, THE RIDDLE OF ALL CONSTITUTIONS: INTERNATIONAL LAW, DEMOCRACY AND THE CRITIQUE OF IDEOLOGY 111 (2000) for a proposition of a principle of democratic inclusion, which is supposed to guide the elaboration and interpretation of international legal norms. However, Marks' contribution does not examine concrete sources of international law. It thus has to be perceived rather as a normative proposition than an analysis of a positive norm of international law.

99 Antonio Cassese, The Self-Determination of Peoples, in ThE InTERnATIONAL BILL OF Rights 92, 97 (Louis Henkin ed., 1981); ideM, Self-Determination of PeOples. A Legal ReAppraisAl 311 (1995); Allan Rosas, Internal Self-Determination, in MODERN LAW OF SELF-DETERMINATION 225, 244-46 (Christian Tomuschat ed., 1993); Patrick Thornbury, The Democratic or Internal Aspect of Self-Determination with some Remarks on Federalism, in MODERn LAW OF SELF-DETERMinATION, supra, at 101, 136-37; Juan Francisco Escudero Espinosa, Hacia una intervención armada en favor de la democracia?: El "precedente" de Haití, 12 ANUARIO DE DERECHO INTERNACIONAL 297, $344-56$ (1996); Daniel Thürer, Self-Determination, in 4 ENCYCLOPEDIA OF PUBLIC INTERNATIONAL LAW 364, 372 (Rudolf Bernhardt ed., 2000); Linos-Alexandre Sicilianos, Les Nations unies et la démocratisation de l'Etat: nouvelles tendances, in LA CONTRIBUTION DES NATIONS UNIES À LA DÉMOCRATISATION DE L'ETAT 13, 24 (Rostane Mehdi ed., 2002); Jean d'Aspremont, La création internationale d'Etats démocratiques, 109 REVUE GÉNÉRALE DE DROIT INTERNATIONAL PUBLIC 889, 905-7 (2005).

100 James Crawford, The Rights of Peoples: 'Peoples' or 'Governments'?, in ThE Right OF PeOPLES 55, 58 (1988).

101 Covenant on Civil and Political Rights, supra note 16, and International Covenant on Economic, Social and Cultural Rights, Dec. 19, 1966, 993 UNTS 3.

102 Cassese, supra note 99, at 97; Christoph Gusy, Selbstbestimmung im Wandel. Von der Selbstbestimmung durch den Staat zur Selbstbestimmung im Staat, 30 ARCHIV DES VÖLKERRECHTS 385, 405 (1992).

103 Declaration on Principles of International Law Concerning Friendly Relations and Co-operation among States in accordance with the Charter of the United Nations, GA Res. 2625 (XXV), at 121, UN Doc. A/5217 (Oct. 24, 1970). 


\section{Democracy as Mandatory Consequence of Self-Determination}

There are two different lines of arguments trying to deduce a democratic principle from the right to self-determination. The first argument is a contextual one: as part of the Covenant on Civil and Political Rights (CCPR) ${ }^{104}$, art. 1 has to be interpreted in the context of the other provisions of the Covenant, in particular the right to democratic elections prescribed in art. 25. The right to participate in elections specifies how the right to determine the own political system has to be exercised. ${ }^{105}$ However, it seems more convincing to interpret both provisions in a way that leaves them an independent normative scope. ${ }^{106}$ If the guarantees of a self-determination principle which is shaped by art. 25 CCPR do not surpass the scope of the right to democratic elections, self-determination is not needed. In order to guarantee elections, art. 25 CCPR is a sufficient normative basis. If one wants to draw further conclusions, a mere connection of and abstraction from basically independent principles is not enough. This becomes obvious if we consider the practical relevance of the discussion. Within the framework of the CCPR, it does not make any difference whether we interpret art. 1 CCPR in the light of art. 25 CCPR because the latter guarantees that elections will be held in any case. This is different for the customary principle of selfdetermination outside the CCPR. If we interpret this principle equally in the light of art. 25 CCPR, then the scope of the electoral guarantee would be impermissibly extended over the limits of the Convention.

The second argument is more fundamental. It tries to establish a logical relationship between democracy and self-determination. Taking seriously that the right to determine the political system is a right of the people, the decision on the political status has to be one of the people, not of the government. Such a decision is necessarily dependent on democratic mechanisms because a different mode of decision attributable to the people is not conceivable. ${ }^{107}$ This 'logical' relationship is, however, based on problematic premises. ${ }^{108}$ It does not distinguish between the act of framing the political system and its actual content, the pouvoir constituant and the pouvoir constitué. $^{109}$ The right to self-determination only refers to the former, but not necessarily to the lat-

\section{See supra note 16.}

105 Cassese, supra note 99, at 97; Alexandre-Charles Kiss, The Peoples' Right to Self-Determination, 7 Hum. RTS. L.J. 165, 171 (1986); Hans A. Stöcker, Europäische Menschenrechtskonvention, Ordre-PublicVorbehalt und nationales Selbstbestimmungsrecht, 14 EUROPÄISCHE GRUNDRECHTE ZEITSCHRIFT 473, 477 (1987); Christian Hillgruber \& Bernhard Kempen, Das Selbstbestimmungsrecht des deutschen Volkes und der Teso-Beschluß des Bundesverfassungsgerichts, 33 RECHT IN OsT UnD WeST 323, 325-26 (1989); Rosas, supra note 99, at 244; Thornbury, supra note 99, at 136-37; Thürer, supra note 99, at 372.

106 Christian Tomuschat, Democratic Pluralism: The Right to Political Opposition, in HumAn Rights ANd PluRALIST DEMOCRACY 27, 40 (Allan Rosas \& Jan Helgesen eds., 1992).

107 Rosas, supra note 99, at 229; Sicilianos, supra note 99, at 24.

108 Cf. also Russel A. Miller, Self-Determination in International Law and the Demise of Democracy?, 41 CoL. J. TRANSNAT'L L. 601 (2003) (making, however, a historical argument against the logical conjunction of democracy and self-determination).

109 See Ernst-Wolfgang Böckenförde, Die verfassunggebende Gewalt des Volkes - Ein Grenzbegriff des Verfassungsrechts, in STAAT, VERFASSUNG, DEMOKRATIE 90, 98-107 (1991) on this distinction. 
ter. History provides examples in which citizens opted by electoral means to delegate power to political elites, which then established authoritarian rule. ${ }^{110}$

One solution to address this dilemma is to distinguish formally between the act of establishing a political system, and the political system itself. The participation of the citizens is limited to the former act. If they choose a system other than democracy, they have, by this act, exhausted their right to self-determination. ${ }^{111}$ This view can, however, not explain why the act of selfdetermination should be irreversible. Votes often do depend on the special circumstances of a certain historic situation. However, circumstances may change, just as citizens' preferences may change. Moreover, the composition of the population itself is subject to change. It is difficult to justify that the citizenry in a historically accidental moment shall have the power to bind future generations.

Another solution has been put forward by Gregory Fox and Georg Nolte in their contribution on 'Intolerant Democracies'. In their analysis, they discuss whether democracies are allowed to fight political tendencies directed against the system as such. ${ }^{112}$ They propose a substantive concept of democracy in which electoral results may be disregarded in order to prevent an undemocratic opposition to come to power and to protect democracy as such. However, this argument implies a predisposition towards democracy. ${ }^{113}$ Democracy or even a specific type of substantive democracy is considered to be an absolute value a priori. We have, however, seen that the value of democracy always depends on the specific circumstances. ${ }^{114}$ We can thus stick to what Alberto Asor Rosa remarked as early as twenty-five years ago:

democracy, precisely because it is a system of mediocrites that cannot make itself out to be an absolute or an end in itself [...], is a game whose defining feature is that it allows its own rules to be called into question. If it does not, it is already something else. ${ }^{115}$

\section{Self-Determination and Representation}

This does, however, not lead to the conclusion that the right to self-determination does not impose any restrictions on the political elites' choice of the form of government. This is expressed in the friendly relations declaration, which declares with regard to the principle of selfdetermination:

110 Jürgen Gebhardt, Das Demokratische Prinzip und die moderne politische Ordnung, in DEMOKRATIE - CHANCEN UND HERAUSFORDERUNGEN IM 21. JAHRHUNDERT 19, 28 (André Kaiser \& Wolfgang Leidhold eds., 2005).

111 Karl Doehring, Demokratie und Völkerrecht, in TRADITION UnD WELTOFFENHEIT DES RECHTS. FESTSCHRIFT FÜr Helmut Steinberger 127, 129 (Hans-Joachim Cremer, Thomas Giegerich \& Dagmar Richter eds., 2002).

112 Gregory H. Fox \& Georg Nolte, Intolerant Democracies, 36 HARV. INT'L L. J. 1 (1995).

113 Martti Koskenniemi, "Intolerant Democracies": A Reaction, 37 HARV. InT'L L. J. 231, 232-33 (1996).

114 See supra Part II.B.

115 Alberto Asor Rosa, La felicità e la politica, 1.2 LABORATORIO Politico 10, 30-31 (1981) ("la democrazia, proprio in quanto sistema delle mediocrità, che non si assolutizza e non si erige esso stesso a fine [...], è qual tale gioco che accetta di rimettere in discussione le proprie regole. Se non lo fa, è già un'altra cosa.”) (Translation by the author, emphasis in the original). 
Nothing in the foregoing paragraphs shall be construed as authorizing or encouraging any action which would dismember or impair, totally or in part, the territorial integrity or political unity of sovereign and independent States conducting themselves in compliance with the principle of equal rights and self-determination of peoples as described above and thus possessed of a government representing the whole people belonging to the territory without distinction as to race, creed or colour. ${ }^{116}$

Consequently, not every form of government is compatible with self-determination. Rather, the government has to be representative. Excluded are thus governments which are authoritarian or only represent particularistic interests. These considerations are underlined by a further argument. If the content of self-determination could exclusively be determined by the respective government, the principle would not differ from the principle of state sovereignty and thus not have any independent value. ${ }^{117}$

However, representation does not necessarily have to be realized through elections. It may also be by government in the public interest, government for the people. The problem will certainly be to determine when a form of government can be considered as representative. Unlike democracy, representativeness cannot be determined by the sole existence of certain institutions. We rather have to recur to substantial criteria. In this respect, a distinction proposed by Georg Sørensen may be helpful. Sørensen distinguishes between development-oriented régimes, whose purpose is economic development as well as the promotion of individual well-being, growthoriented régimes, who focus exclusively on economic growth without taking into account its effects on society, and self-enriching régimes. ${ }^{118}$ Only the first type can be regarded as compatible with the right to self-determination. A further indicator is the human rights record of a government. Not every violation of human rights accounts for the illegitimacy of a government as human rights violations occur even in the most advanced political systems. ${ }^{119}$ However, in cases of systematic violations of core human rights, the government would not be representative of its citizens anymore. It would be to qualify as illegitimate, and the state would infringe upon the right to self-determination of its population.

\section{B. The International Practice: Democratic Teleology}

In contrast to the deductive approach, the inductive approach relies in particular on the practice of international institutions. ${ }^{120}$ The argumentation is based on a thin concept of democracy,

116 Friendly relations declaration, supra note 103 (emphasis added).

117 Crawford, supra note 100, at 56.

118 SØRENSEN, supra note 79, at 76-81.

119 Certainly, a state remains responsible for its human rights violations even if they do not cross the threshold to illegitimacy.

120 See Franck, supra note 3; Fox, supra note 3; David Wippman, Defending Democracy through Foreign Intervention, 19 Houston J. INT'L L. 659, 665-68 (1997); Roland Rich, Bringing Democracy into International Law, 12.3 J. DEM. 20 (2001); Fulda, Demokratie und pacta sunt servanda (2002); Sicilianos, supra note 99; Christian Tomuschat, L'intervention structurelle des Nations unies, in LA CONTRIBUTION DES NATIONS UNIES À LA DÉMOCRATISATION DE L'ETAT 101 (Rostane Mehdi ed., 2002); JUDE I. IBEGBU, RIGHT TO DEMOCRACY IN INTERNATIONAL LAW 141-205 (2003); Dodzi Kokoroko, Souveraineté étatique et principe de légitimité démocratique, 16 REVUE QUÉBÉCOISE DE DROIT INTERNATIONAL 37 (2003); Jan Wouters, Bart De Meester \& 
which is principally identified by periodic elections. ${ }^{121}$ Further support is drawn from political human rights like the freedoms of speech, assembly and association. ${ }^{122}$ However, democratization is more complex than just being the introduction of a simple assembly of certain political rights and institutions. The debate in legal academia often seems to presuppose that democracy can easily be established in any given state. But the establishment of democracy was already a complex and slow development in the Western hemisphere. Many developing countries are in a different social and economic situation than most Western states were when they began their transition to democracy. When establishing our theoretical framework, we have already seen that democratization is a complex and long-term process. ${ }^{123}$ Therefore, this section tries to reexamine the evidence on democracy in international law through the lens of democratization theory. The thesis which shall be put forward is that international law does not know a strict right to democratic governance, but rather contains a principle of democratic teleology. States are not required to introduce democracy right away, but to develop towards democracy.

Evidence for the emergence of a democracy principle can be found in various fields of international law. The following analysis shall concentrate on three areas, which I deem especially important. First, we will have a look at universal human rights instruments and the practice of international institutions, like resolutions of the UN General Assembly (1.). Then, we will briefly examine the institutional practice at the regional level (2.), before finally dealing with the issue of military interventions in order to establish democracy (3.).

\section{Practice of International Institutions}

\section{(a) Right to Democratic Elections: CCPR and UDHR}

One strong indicator for the existence of customary international law is universal treaties, such as the international human rights instruments. If states enter into treaty obligations, they express their intent to be bound by the treaty norms and thus manifest a corresponding opinio iuris. ${ }^{124}$ The most important treaty norm in this context is art. 25 CCPR. It guarantees the participation in genuine, periodic elections, which are supposed the guarantee the free expression of the will of the electors. Although socialist states originally argued - based on the travaux préparatoire that one-party systems would be in conformity with art. 25 CCPR, there is consensus among international legal scholars today that voters have to be given a meaningful choice in order to meet

Cedric Ryngaert, Democracy and International Law, 34 NETH. Y.B. InT’L L. 137 (2003); Tom J. Farer, The promotion of democracy: International law and norms, in THE UN ROLE IN PROMOTING DEMOCRACY: BETWEEN IDEALS AND REALITY 32 (Edward Newman \& Roland Rich eds., 2004); Juliane Kokott, Souveräne Gleichheit und Demokratie im Völkerrecht, 64 HEIDELBERG J. INT’L L. 517, 526-27 (2004); WHEATLEY, Supra note 13, at 135-36; Attila Tanzi, Remarks on Democracy in Contemporary International Law, 61 LA COMUnitÀ INTERNAZIONALE 289 (2006); Christian Pippan, Gibt es ein Recht auf Demokratie im Völkerrecht?, in POPPER UND DIE MENSCHENRECHTE 119, 137-60 (Erwin Riefler ed., 2007).

121 JAMES CRAWFORD, DEMOCRACY IN INTERNATIONAL LAW 25 (1993).

122 See Franck, supra note 3, at 61; Fulda, supra note 120, at 22; Sicilianos, supra note 99, at 30.

123 See supra Part II.B.5.

124 North Sea Continental Shelf (F.R.G. v. Den.), 1969 I.C.J. 4, at para. 71 (Feb. 20). See generally Richard R. Baxter, Treaties and Custom, 129 RECUEIL DES COURS 25 (1970) on the issue of treaties as indicators for customary law. 
the requirements of the Covenant. ${ }^{125}$ A "free expression of the will of the electors" (lit. b) and the "part[icipation] in the conduct of public affairs" (lit. a) is only possible when the voters' choice is not restricted to a choice of persons, but also to one of different political agendas. ${ }^{126}$

The CCPR has, as yet, been ratified by 160 states. ${ }^{127}$ Indeed, more than eighty percent of the international community have agreed to select their government by free and fair elections. However, there are notable exceptions - the abstinent states China and Pakistan belong to the ten most populous states in the world. Furthermore, the list of abstaining countries shows patterns of regional concentration. Especially in East and Southeast Asia, ${ }^{128}$ a considerable number of states has not committed itself to hold periodic elections. Moreover, the number becomes less impressive when we take a look at the actual state practice. Many of the states having ratified the CCPR do not actually practice electoral democracy. According to the 2007 survey of Freedom House, only two thirds of the members of the international community of states can be qualified as electoral democracies. ${ }^{129}$ Mere commitment to art. 25 CCPR alone is thus not sufficient in order to establish a customary principle of democracy. ${ }^{130}$ Art. 21 of the Universal Declaration of Human Rights $^{131}$ encounters the same problem. Indeed, in para. 3, this norm establishes a right to participate in periodic and genuine elections - however, this declaration equally is not supported by state practice.

125 Karl Josef Partsch, Freedom of Conscience and Expression, and Political Freedoms, in THE INTERNATIONAL BILl OF Rights 209, 240 (Louis Henkin ed., 1981); Gregory H. Fox, The right to political participation in international law, in DEMOCRATIC GOVERNANCE AND INTERNATIONAL LAW 48, 57-59 (Gregory H. Fox \& Brad R. Roth eds., 2000); MANFRED NOWAK, art. 25, in UN COVENANT ON CIVIL AND POLITICAL RIGHTS I 20 (2nd ed. 2005); SARAH JOSEPH, JENNY SCHULTZ \& MELISSA CASTAN, THE INTERNATIONAL Covenant on Civil And Political Rights 922.31 (2nd ed. 2004); Niels Petersen, Elections, Right to Participate in, International Protection, in MAX PlanCK ENCYCLOPEDIA OF PUBLIC INTERNATIONAL LAW 94 (Rüdiger Wolfrum ed., forthcoming 2009).

126 Cf. Bwalya v. Zambia, Comm. No. 314/1988, ø 6.6, U.N. Doc. CCCPR/C/48/D/ 314/1988 (Hum. Rts. Comm. 1988)

127 Status: Jan. 25, 2008. The states, which have not (yet) ratified the Covenant are Antigua and Barbuda, Bahamas, Bhutan, Brunei, China, Comoros, Cuba, Fiji, Guinea-Bissau, Kiribati, Laos, Malaysia, Marshall Islands, Micronesia, Moldova, Myanmar, Oman, Pakistan, Palau, Papua New Guinea, Saint Kitts and Nevis, Saint Lucia, Samoa, São Tomé and Príncipe, Saudi Arabia, Singapore, Solomon Islands, Tonga, Tuvalu, United Arab Emirates, Vanuatu.

128 Bhutan, Brunei, China, Laos, Malaysia, Myanmar, Pakistan, Singapore.

129 Freedom House, Freedom in the World. Selected Data from Freedom House's Global Annual Survey of Political Rights and Civil Liberties (2007), 95.

130 VALENTINA GRADO, GuerRe CIVILI E TERZI STATI 260 (1998); Dietrich Schindler, Völkerrecht und Demokratie, in LIBER AMICORUM PROFESSOR SEIDL-HOHENVELDERN - IN HONOUR OF HIS 80TH BIRTHDAY 611, 622 (Gerhard Hafner et al. eds., 1998); BRAD R. ROTH, GOVERNMENTAL ILLEGITIMACY IN INTERNATIONAL LAW 417 (1999); Stefan Talmon, Who is a Legitimate Government in Exile? Towards Normative Criteria for Governmental Legitimacy in International Law, in THE REALITY OF INTERNATIONAL LAW. ESSAYS IN HONOUR OF IAN BROWNLIE 499, 534 (Guy S. Goodwin-Gill \& Stefan Talmon eds., 1999); Mirko Zambelli, La démocratie: principe universel et fondamental de l'ordre juridique international?, 10 AKTUELLE JURISTISCHE PRAXIS 667, 673 (2001); Wheatley, supra note 22, at 233; Same Varayudej, A Right to Democracy in International Law: Its Implications for Asia, 12 ANN. SuRV. INT'L \& COMP. L. 1, 17 (2006). However, see also the opposing evaluations of Fulda, supra note 120, at 86; Nigel D. White, The United Nations and Democracy Assistance: Developing Practice within a Constitutional Framework, in DEMOCRACY ASSISTANCE. INTERNATIONAL Co-OPERATION FOR DEMOCRATIZATION 67, 72 (Peter Burnell ed., 2000); Thomas M. Franck, Legitimacy and the democratic entitlement, in DEMOCRATIC GOVERNANCE AND INTERNATIONAL LAW 25, 27 (Gregory H. Fox \& Brad R. Roth eds., 2000).

131 Universal Declaration of Human Rights, G.A. Res. 217 A (III), at 71, U.N. GAOR, 3d Sess., 1st plen. mtg., U.N. Doc. A/810 (Dec. 12, 1948). 


\section{(b) Declarations of the U.N. General Assembly}

A more modest approach is put forward by the UN General Assembly in a couple of resolutions on elections and democracy. From 1988 onwards, the General Assembly issued a series of resolutions under the title "Enhancing the Effectiveness of the principle of periodic and genuine elections““. ${ }^{132}$ The first resolution of this series states in its operative part that the General Assembly

1. Emphasizes the significance of the Universal Declaration of Human Rights and the International Covenant on Civil and Political Rights, which establish that the authority to govern shall be based on the will of the people, as expressed in periodic and genuine elections;

2. Stresses its conviction that periodic and genuine elections are a necessary and indispensable element of sustained efforts to protect the rights and interests of the governed and that, as a matter of practical experience, the right of everyone to take part in the government of his or her country is a crucial factor in the effective enjoyment by all of a wide range of other human rights and fundamental freedoms, including political, economic, social, and cultural rights;

3. Declares that determining the will of the people requires an electoral process which accommodates distinct alternatives, and this process should provide an equal opportunity for all citizens to become candidates and put forward their political views, individually and in co-operation with others; ${ }^{133}$

The resolution does not contain an explicit affirmation of a right to democratic elections. Instead of imposing a strict obligation, the resolution rather gives reasons for the suitability of elections. Para. 2 attempts an empirical justification ("as a matter of practical experience”) and emphasizes that elections are a necessary precondition for output legitimacy ("to protect the rights and interests of the governed”) because they are crucial for the enjoyment of human rights. In contrast, para. 3 is of normative nature, referring to the will of the people and stressing the necessity to implement the latter through an electoral process.

The resolution was changed slightly in the following years. The successive versions of the resolution contained reservations stressing the autonomy of states to develop their political system. Resolution 46/137, which was adopted in 1991, stated in its preamble:

Recognizing that there is no single political system or electoral method that is equally suited to all nations and their people and that the efforts of the international community to enhance the effectiveness of the principle of periodic and genuine elections should not call into question each State's sovereign right, in accordance with the will of its people, freely to choose and develop its political, social, economic

132 G.A. Res. 43/157, U.N. Doc. A/RES/43/157 (Dec. 8, 1988); G.A. Res. 44/146, U.N. Doc. A/RES/44/146 (Dec. 15, 1989); G.A. Res. 45/150, U.N. Doc. A/RES/45/150 (Dec. 18, 1990); G.A. Res. 46/137, U.N. Doc. A/RES/46/137 (Dec. 17, 1991); G.A. Res. 47/138, U.N. Doc. A/RES/47/138 (Dec. 18, 1992); G.A. Res. 48/131, U.N. Doc. A/RES/48/131 (Dec. 20, 1993); G.A. Res. 49/190, U.N. Doc. A/RES/49/190 (Dec. 23, 1994); G.A. Res. 50/185, U.N. Doc. A/RES/50/185 (Dec. 15, 1995); G.A. Res. 52/129, U.N. Doc. A/RES/52/129 (Dec. 12, 1997); G.A. Res. 54/173, U.N. Doc. A/RES/54/173 (Dec. 17, 1999); G.A. Res. 56/159, U.N. Doc. A/RES/56/159 (Dec. 19, 2001); G.A. Res. 58/180, U.N. Doc. A/RES/58/180 (Dec. 22, 2003); G.A. Res. 60/162, U.N. Doc. A/RES/60/162 (Dec. 16, 2005); G.A. Res. 62/150, U.N. Doc. A/RES/62/150 (Dec. 18, 2007).

133 G.A. Res. 43/157, supra note 132 (emphasis added). 
and cultural systems, whether or not they conform to the preferences of other states. ${ }^{134}$

Furthermore, in the operative part, it said:

5. Underscores the duty of each Member State, in accordance with the provisions of the Charter of the United Nations, to respect the decisions taken by other states, in accordance with the will of their people, in freely choosing and developing their electoral institutions; ${ }^{.35}$

Concurrently, the General Assembly adopted, from 1989 onwards, a "counter”-resolution, bearing the title "Respect for he principles of national sovereignty and non-interference in the internal affairs of states in their electoral processes", ${ }^{136}$ which stresses in its operative part the right of peoples to determine their political, economic and social system:

[The General Assembly]

1. Reiterates that, by virtue of the principle of equal rights and self-determination of peoples enshrined in the Charter of the United Nations, all peoples have the right, freely and without external interference, to determine their political status and to pursue their economic, social and cultural development, and that every State has the duty to respect that right in accordance with the provisions of the Charter;

2. Affirms that it is the concern solely of peoples to determine methods and to establish institutions regarding the electoral process, as well as to determine the ways for its implementation according to their constitution and national legislation;

$[\ldots]$

4. Urges all States to respect the principle of non-interference in the internal affairs of States and the sovereign right of peoples to determine their political, economic and social system. ${ }^{137}$

At first glance, the two strands of resolutions seem to contradict each other. ${ }^{138}$ On the one hand, the pro-elections resolutions praise the advantages of electoral systems of government. But these praises are taken away with the other hand emphasizing the importance of national autonomy to

134 G.A. Res. 46/137, supra note 132 (emphasis added). The two preceding resolutions from 1989 and 1990 still had this paragraph in the operative part instead of the preamble.

135 Id. (emphasis added).

136 G.A. Res. 44/147, U.N. Doc. A/RES/44/147 (Dec. 15, 1989); G.A. Res. 45/151, U.N. Doc. A/RES/45/151 (Dec. 18, 1990); G.A. Res. 46/130, U.N. Doc. A/RES/46/130 (Dec. 17, 1991); G.A. Res. 47/130, U.N. Doc. A/RES/47/130 (Dec. 18, 1992); G.A. Res. 48/124, U.N. Doc. A/RES/48/124 (Dec. 20, 1993); G.A. Res. 49/180, U.N. Doc. A/RES/49/180 (Dec. 23, 1994); G.A. Res. 50/172, U.N. Doc. A/RES/50/172 (Dec. 22, 1995); G.A. Res. 52/119, U.N. Doc. A/RES/52/119 (Dec. 12, 1997); G.A. Res. 54/168, U.N. Doc. A/RES/54/168 (Dec. 17, 1999). From 2001, the resolutions were adopted with a different operative part stressing the relationship between the right to self-determination of the political system and the development of electoral institutions: G.A. Res. 56/154, U.N. Doc. A/RES/56/154 (Dec. 19, 2001); G.A. Res. 58/189, U.N. Doc. A/RES/58/189 (Dec. 22, 2003); G.A. Res. 60/164, U.N. Doc. A/RES/60/164 (Dec. 16, 2005).

137 G.A. Res. 44/147, supra note 136 (emphasis added).

138 Slim Laghmani, Vers une légitimité démocratique?, in LES NOUVEAUX ASPECTS DU DROIT INTERNATIONAL 249, 269 (Rafâa Ben Achour \& Slim Laghmani eds., 1994) (“exacte négation”). Accord. Rafâa Ben Achour, Egalité souveraine des Etats, droit des peuples à disposer d'eux-mêmes et liberté de choix du système politique, économique, culturel et social, in SOLIDARITÉ, ÉGALITÉ, LIBERTÉ - FREDERICO MAYOR AMICORUM LIBER 785, 793 (Karel Vasak et al. eds., 1995). 
choose a proper political system without external interference. However, the contradiction is not as great as some scholars would like it to appear. Even if peoples have the right to determine their political, economic and social system, this does not mean that the choice of the political system is unlimited. As we have seen in the previous section, the government has to be representative. ${ }^{139}$ Para. 5 of resolution $46 / 137$ underlines this by emphasizing that the choice has to be made "in accordance with the will of the people”. Considering the difficulties of equalizing the pouvoir constituant and the pouvoir constitué, ${ }^{140}$ this does, however, not constitute an automatic obligation to democracy.

The resolutions rather suggest a teleological attitude towards elections and democracy. They emphasize the desirability of electoral institutions without imposing a strict obligation. In our analysis of the democratization theories, we have seen that democratization is perceived as a longterm process rather than a shift from one status to another. ${ }^{141}$ By using the terms "developing” or "enhancing" in the context of electoral institutions, the language of the resolution stresses exactly this process-like character of democratization. The establishment of electoral institutions is only one element, not necessarily the first in this process.

These results are underlined by several other resolutions and declarations of the international community. The primary example is General Assembly resolution 55/96, titled "Promoting and Consolidating Democracy”, which was adopted in 2000. The central claim of this resolution is to "call upon states to promote and consolidate democracy". ${ }^{142}$ Thus, it equally uses a processoriented terminology by employing terms such as "promoting” and "consolidating”. In particular, the latter term is often used in the social sciences to describe the teleological character of democratization processes. ${ }^{143}$ Furthermore, the term "consolidation" underlines that democracy is understood both as a classificatory and as a gradual concept in international law. The process of democratization certainly marks the process leading to a transition to democracy. It does, however, not stop there, but requires also a subsequent consolidation.

The aforementioned Vienna Declaration of Human Rights ${ }^{144}$ also contains a paragraph dedicated to democratization:

The World Conference on Human Rights reaffirms that least developed countries committed to the process of democratization and economic reforms, many of which are in Africa, should be supported by the international community in order to succeed in their transition to democracy and economic development. ${ }^{145}$

Again, the language rather focuses on democratization and the process of transition than on the status of democracy. Finally, in the UN millennium declaration ${ }^{146}$ we can find several declara-

139 See supra Part III.A.2.

140 See supra Part III.A.1.

141 See supra Part II.B.5.

142 G.A. Res. 55/96, supra note 17, ๆ 1.

143 Schedler, supra note 93, at 95.

144 Supra note 4.

145 Vienna Declaration, supra note 4, ๆ 9.

146 United Nations Millennium Declaration, G.A. Res. 55/2, U.N. Doc. A/RES/55/2 (Sept. 8, 2000). 
tions to promote democracy ${ }^{147}$ or to strengthen the capacity of UN member states for democratization $^{148}$.

\section{Regional Developments}

Indications for an increasing acceptance of democracy as an international legal principle cannot only be found at universal, but also at regional level. As the following analysis will show, there are, however, significant differences between the various regions.

\section{(a) Americas}

\section{( $\alpha$ ) Organization of American States}

The most extensive guarantees concerning democracy - outside the European Union - can be found in the system of the Organization of American States (OAS). On the one hand, art. 23 of the American Convention of Human Rights ${ }^{149}$ prescribes the right to participate in democratic elections. Furthermore, the promotion of democracy is, according to art. 2 lit. b of the OAS Charter ${ }^{150}$, one of the principal objectives of the organization. Art. 9 of the OAS Charter provides the possibility to suspend membership rights of a Member State if the elected government of the latter has been overthrown by force. The mechanism governing the suspension of membership rights has been outlined in a more detailed way in the Inter-American Democratic Charter $^{151}$, which was adopted by the OAS General Assembly on September 11, 2001. ${ }^{152}$ The Charter guarantees the American peoples a right to democracy and establishes an implementation mechanism in its art. 17-22. Although, as resolution of the General Assembly the democratic Charter has no directly binding force, the established implementation mechanism can, according to art. 31 of the Vienna Convention on the Law of Treaties (VCLT) ${ }^{153}$, be regarded as specification of OAS Charter art. 9. ${ }^{154}$

This sanction mechanism has been applied several times in practice. The baptism of fire came shortly after the adoption of resolution 1080, when Haiti's president Aristide was ousted in September 1991. The Permanent Council convened immediately, condemned the coup and requested the reinstallation of Aristide. ${ }^{155}$ Two days later, the OAS suspended the trade relations with Haiti

147 See id. at I 24 ("We will spare no effort to promote democracy and strengthen the rule of law [...]").

148 See id. at 225 ("We resolve therefore: [...] To strengthen the capacity of all our countries to implement the principles and practices of democracy [...]”).

149 American Convention on Human Rights, supra note 16.

150 Charter of the Organization of American States, Apr. 30, 1948, 119 U.N.T.S. 3.

151 Inter-American Democratic Charter, O.A.S. Doc. OEA/Ser.P/AG/Res.1 (XXVIII-E/01) (Sept. 11, 2001).

152 See Enrique Lagos \& Timothy D. Rudy, The Third Summit of the Americas and the Thirty-first Session of the OAS General Assembly, 96 AM. J. INT'L L. 173 (2002); Enrique Lagos \& Timothy D. Rudy, In Defense of Democracy, 35 U. Miami Inter-Am. L. Rev. 283 (2004); Sonia Picado, The Evolution of Democracy and Human Rights in Latin America: A Ten Year Perspective, 11 HUM. RTS. BRIEF 28 (2004) for more detailed accounts of the Charter. 
and all forms of non-humanitarian aid. ${ }^{156}$ Subsequently, the United Nations assumed the case. Two years after the coup, they finally authorized the United States to intervene with military means, thus forcing the military junta to step down. ${ }^{157}$

In April 1992, the Peruvian president Fujimori staged an auto-coup, in which he dissolved the parliament and commanded the arrest of several members of the opposition. The Permanent Council of the OAS expressly condemned this action. ${ }^{158}$ The international community suspended several loans which had been envisaged to support the country. The international pressure prompted Fujimori to concede the election of a constitutional assembly in November 1992. The effectiveness of these international measures was limited, however, as Fujimori won the elections and maintained his power in the end. ${ }^{159}$ One year later, Jorge Serrano Elías, the president of Guatemala, also initiated an auto-coup. He dissolved the parliament, suspended several constitutional rights and dismissed the judges of the constitutional court. The sanctions of the OAS were much more severe than in the case of Peru. ${ }^{160}$ The Permanent Council condemned Serrano's coup unanimously and forced him finally to step down and to flee to El Salvador.

In 2000, Peru again came into the focus of public attention. The OAS sent a mission to Peru in order to monitor the presidential elections. However, the monitoring mission perceived itself to be unable to guarantee the technical minimum standards for the vote counting of the decisive ballot between Fujimori and his contender, Alejandro Toledo. The OAS thus canceled the mission. In its report to the Secretary General, the delegation called the elections insufficient with regard to international standards. ${ }^{161}$ Despite this report, the member states of the OAS could not agree to condemn Peru on the basis of resolution 1080. The Permanent Council adopted a compromise and sent a mission to Peru in order to investigate the case in more detail. The mission was, however, not completed because Fujimori stumbled on a corruption scandal and had to cede power.

In February 2004, Haiti's president Aristide was toppled a second time. A three-week rebellion forced him to step down and to leave the country. The president of the Supreme Court, Boniface Alexandre, succeeded Aristide as transitional president. The reaction of the international community was much more lukewarm than thirteen years earlier. The General Assembly of the OAS reacted four months later, adopting a resolution in which it called upon Haiti to return to democracy and condemning the committed acts of violence. ${ }^{162}$ However, the OAS neither authorized

156 O.A.S. Doc. MRE/RES. 1/91, Ser. F/V.1 (Oct. 3, 1991).

157 See infra Part III.B.3.b (referring to the case of Haiti in more detail).

158 O.A.S. Doc. MRE/RES. 1/92, Ser. G (Apr. 13, 1992)

159 Tom J. Farer, Collectively Defending Democracy in the Western Hemisphere, in BEYOND SOVEREIGNTY: Collectively Defending Democracy in the AMERiCAs 1, 19-20 (1996).

160 See Barry Steven Levitt, A Desultory Defense of Democracy: OAS Resolution 1080 and the Inter-American Democratic Charter, 48.3 LATIN AM. POL. \& SOC'Y 93, 116 (2006) (noting that the reason for the different treatment was probably that the Peruvian people backed Fujimori more than the population of Guatemala did Serrano).

161 O.A.S. Doc. CP/ACTA 1241/00, Ser. G (May 31, 2000).

162 O.A.S. Doc. AG/RES. 2058 (XXXIV-O/04) (June 8, 2004). 
formal sanctions, nor did it suspend membership rights. ${ }^{163}$ The reason for this mild international reaction was probably Aristide's weak legitimacy. ${ }^{164}$ He had still been elected in 2000, but the elections had been subject to irregularities. Furthermore, many human rights organizations condemned Aristide for the deteriorating human rights situation and the political violence in the country. This case demonstrates that the OAS treats coups d'état in a differentiated manner. Not every coup is automatically condemned. Rather, the perceived legitimacy of the ousted head of state has a decisive influence on the reaction of the OAS.

\section{(ß) Regional Organizations}

References to democracy are, however, not limited to the OAS. Legal documents referring to democracy and elections can also be found in the framework of some Latin American regional organizations. In 1998, the Member States of the Andean Community (Comunidad Andina CAN) adopted the Andean Community Commitment to Democracy ${ }^{165}$ as a legally binding additional protocol to the founding statute of the CAN, the Cartagena Agreement. ${ }^{166}$ Save a commitment to democracy in art. 1, the protocol sets up a sanction mechanism (art. 4), which enables coercive measures ranging from the suspension of membership rights (lit. a) to the disallowance of the eligibility for loans of the financial institutions of the CAN (lit. c) if the democratic order is disrupted (art. 2). Furthermore, art. 13 of the Human Rights Charter of the $\mathrm{CAN}^{167}$ prescribes a right of the Andean peoples to democracy, which is further specified in the arts. 14-18.

A similar mechanism was installed in the framework of the MERCOSUR. In 1996, the heads of state of the four Member States adopted a declaration for democracy ${ }^{168}$, in which the establishment and maintenance of democratic institutions is regarded as a fundamental precondition for the cooperation within the MERCOSUR (para. 1). Violations may lead to the suspension of membership rights (para. 4). With the protocol of Ushuaia ${ }^{169}$, this mechanism has been transformed into an international treaty that has been extended also to Bolivia and Chile, countries not currently members of the MERCOSUR.

The system of Central American Integration (Sistema de Integración Centroamericana - SICA) has included the promotion and strengthening of democracy as one of the principal objectives of

163 David S. Berry, Non-Democratic Transitions: Reactions of the OAS and CARICOM to Aristide's Departure, 33 SYRACUSE J. INT'L L. \& COM. 249, 256 (2005).

164 Michele Wucker, Haiti: So Many Missteps, 21.1 WorLd PoL'Y J. 41 (2004).

165 Additional Protocol to the Cartagena Agreement: “Andean Community Commitment to Democracy”, Aug. 7, 1998, http://www.comunidadandina.org/INGLES/normativa/ democracy.htm.

166 Andean Subregional Integration Agreement (Cartagena Agreement), May 26, 1969, 28 I.L.M. 1165.

167 Andean Charter for the Promotion and Protection of Human Rights, Jul. 26, 2002, http://www.comunidadandina.org/INGLES/documentos/documents/andean_charter.htm.

168 Declaración Presidencial sobre Compromiso Democrático en el MERCOSUR, June 25, 1996, http://www.mercosursalud.org/espanhol/mercosul/historico/Decl_compr_Pres.htm.

169 Protocolo de Ushuaia sobre Compromiso Democrático en el MERCOSUR, la Republica de Bolivia y la Republica de Chile, July 24, 1998, http://www.mercosur.int/msweb/portal\%20intermediario/es/index.htm (follow "Protocolo de Ushuaia" hyperlink). 
the organization into art. 3 of its founding statute, the protocol of Tegucigalpa. ${ }^{170}$ This objective was confirmed in 1995 by concluding the treaty on democratic security in Central America ${ }^{171}$, which affirms that SICA is based on the principles of democracy and the rule of law, leading to the obligation to elect governments in universal, free and secret elections (art. 1 (1)).

\section{(b) Europe}

As for the Americas, the institutional design of Europe's international organisations shows a great commitment to democracy. Art. 3 of the first additional protocol to the European Convention on Human Rights ${ }^{172}$ prescribes the right to participate in democratic elections. In contrast to the OAS, however, the democracy principle has not been enshrined in the founding Statute of the Council of Europe ${ }^{173}$. In its art. 3, it says that the Member States „must accept the principles of the rule of law and of the enjoyment by all persons within its jurisdiction of human rights and fundamental freedoms, and collaborate sincerely and effectively in the realisation of the objective of the Council as specified in Chapter I.”

Although missing in the operative part of the statute, democracy is mentioned in the preamble. There, democracy is described as a value which originates from the "spiritual and moral values which are the common heritage of the [European] peoples". ${ }^{174}$ According to art. 1 lit. a of the Statute, the realization of the latter principles is one of the main objectives of the organization.

In practice, the level of democratization had an influence on the membership in the Council of Europe. When, in 1967, the parliamentary democracy in Greece was succeeded by a military dictatorship, the parliamentary assembly recommended the exclusion of Greece to the Committee of Ministers. Greece preceded this step by quitting the Council of Europe on December 12, 1969. Equally, Portugal and Spain were admitted as members only after the reintroduction of democracy in both countries. ${ }^{175}$ After the dissolution of the Soviet Union, the admission of Russia to the Council was delayed for several years. The reason was, inter alia, a report of experts testifying about Russia that it had departed on its journey towards democracy, but had not yet arrived. $^{176}$

In the context of the Conference for Security and Cooperation in Europe, the Heads of State and Government declared in the Charter of Paris that they would promote democracy as the only admissible form of government. In essence, the democracy principle is specified as an implementa-

170 Protocolo de Tegucigalpa a la Carta de la Organización de Estados Centroamericanos (ODECA), Dec. 13, 1991, 1695 U.N.T.S. 382.

171 Tratado Marco de Seguridad Democrática in Centroamérica, Dec. 15, 1995, 2007 U.N.T.S. 191.

172 Protocol to the Convention fort he Protection of Human Rights and Fundamental Freedoms, March 20, 1952, E.T.S. No. 9.

173 Statute of the Council of Europe, May 5, 1949, E.T.S. No. 1.

174 Id. at PP. 3.

175 YVES BEIGBEDER, InTERNATIONAL MONITORING OF PlEBISCITES, REFERENDA AND NATIONAL ELECTIONS 249 (1994).

176 Ronald St. J. Macdonald, The Entry of New Member States into the Council of Europe, 91 ASIL PROCEEDINGS 523 (1997). 
tion of the will of the people by means of free and fair elections and the respect of the rule of law. Although the Charter of Paris is no international treaty with immediately binding force, it can - according to VCLT art. 31 - be used as a tool of interpretation in order to specify existing obligations such as those of the Council of Europe. ${ }^{177}$

The supranational institution, in which the democracy principle is developed the strongest - but in which it is also criticized the most - is the European Union. ${ }^{178}$ According to art. 6 (1) of the Treaty on European Union ${ }^{179}$, democracy is one of the fundamental principles of the EU. It is part of the acquis communautaire, which every potentially new member has to observe in order to be admitted to the EU. Moreover, TEU art. 7 provides a sharp mechanism of sanctions according to which certain membership rights may be suspended if TEU art. 6 (1) is violated. ${ }^{180}$

\section{(c) Africa}

\section{(a) African Union}

In the context of the African Union (AU), art. 13 of the African Charter on Human and Peoples' Rights ${ }^{181}$ does not mention a right to elections explicitly. However, it guarantees a right to participate in the conduct of public affairs. According to the African Commission on Human Rights, this participation requires the legitimation of sovereign power through elections. ${ }^{182}$ Furthermore, art. 3 lit. g and art. 4 lit. $\mathrm{m}$ of the AU Charter ${ }^{183}$ mention the promotion and the respect of democratic principles and institutions as a fundamental objective of the AU. Moreover, the AU and its predecessor, the Organization of African Unity (OAU), have established protection mechanisms against coups d'état. The beginning was a resolution of the African Commission of Human Rights, dating from 1994, which condemned military overthrows of government and appealed to military regimes to transfer their power to elected governments. ${ }^{184}$

177 Jochen Abr. Frowein, Demokratie und Völkerrecht in Europa, in VÖLKERRECHT ZWISCHEN NORMATIVEM ANSPRUCH UND POLITISCHER REALITÄT 365, 368 (Konrad Ginther et al. eds., 1994).

178 See, e.g., Joseph H.H. Weiler, Ulrich Haltern \& Franz C. Mayer, European Democracy and Its Critique, 18 W. EUR. Pol. 4 (1995); Renaud Dehousse, Beyond representative democracy: constitutionalism in a polycentric polity, in European Constitutionalism Beyond the State 135 (Joseph H.H. Weiler \& Marlene Wind eds., 2003); Anne Peters, European Democracy after the 2003 Convention, 41 COM. MKT. L. REV. 37 (2004); Augustín José Menéndez, Between Laeken and the Deep Blue Sea: An Assessment of the Draft Constitutional Treaty from a Deliberative-Democratic Standpoint, 11 EUR. PUBL. L. 105 (2005); Niels Petersen, The Democracy Concept of the European Union - Coherent Constitutional Principle or Prosaic Declaration of Intent?, in The Unity of THE EURopeAn Constitution 97 (Philipp Dann \& Michal Rynkowski eds., 2006) (proposing different conceptualizations of the democracy principle in the EU).

179 Treaty on European Union, Feb. 7, 1992, O.J. C 325 (Dec. 24, 2002) [hereinafter: TEU].

180 See AMARYLLIS VERHOEVEN, THE EUROPEAN UNION IN SEARCH OF A DEMOCRATIC AND CONSTITUTIONAL THEORY 349-354 (2002) on the sanction mechanism established by TEU art. 7.

181 African (Banjul) Charter of Human and Peoples’ Rights, Jun. 27, 1981, 21 I.L.M. 58.

182 Constitutional Projects and Civil Liberties Organisation v. Nigeria, Communication 102/93, in: Twelth Annual Activity Report of the African Commission on Human and Peoples’ Rights - 1998-1999, at 45, I 50.

184 Resolution on the Military, Afr. Comm. Hum. \& Peoples’ Rts., Res. 10(XVI)94 (1994). 
In practice, the turning point was the ousting of Ahmed Kabbah in Sierra Leone in $1997 .{ }^{185}$ The OAU supported the military intervention of the ECOWAS ${ }^{186}$ and called upon the international community to deny the recognition to the junta of Paul Koroma. ${ }^{187}$ It reacted similarly in response to military coups on the Comoros, in the Ivory Coast and in Niger and did not recognize the rebels as legitimate governments of the respective states. ${ }^{188}$

This position was translated into a legal rule with the foundation of the AU. The AU Charter contains, beneath the mentioned commitments to democracy, a condemnation of unconstitutional coups d'état (art. 4 lit. p). The implementation mechanism is embodied in art. 30 of the AU Charter, according to which membership rights of states, in which the government has come to power by unconstitutional means, may be suspended. Reading AU Charter art. 30 together with the guarantee of the democracy principle in art. 4 lit. $\mathrm{m}$ of the Charter suggests an interpretation of art. 30 according to which only the ousting of elected regimes is subject to the mentioned sanctions. $^{189}$

The sanctions mechanism is specified by a declaration of the Heads of State and Government of the AU/OAU. ${ }^{190}$ The declaration provides a period of six months in which the concerned state shall have the opportunity to restore its constitutional order. During this time, it shall be suspended from the policy-making organs of the AU/OAU. If it does not comply with this obligation, sanctions may be instituted. The declaration contains a non-exhaustive list of possible sanctions, ranging from the denial of visas for members of the government in question, via restriction of government-to-government contacts, to trade restrictions.

The mechanism has been applied in several cases. The participation of the Central African Republic in the organs of the AU was suspended after the elected president Ange-Félix Patassé had been overthrown by military force. ${ }^{191}$ The suspension was withdrawn after presidential elections had been held in 2005. ${ }^{192}$ As Faure Gnassingbé captured power in Togo by military force after the death of his father in February 2005, the AU condemned the coup, suspended Togo's membership rights and welcomed the sanctions which had been established by the ECOWAS. ${ }^{193}$ This pressure prompted Gnassingbé to step down and hold elections, which he finally won. The Peace and Security Council reacted by readmitting Togo’s government. ${ }^{194}$

185 Paul D. Williams, From Non-Intervention to Non-Indifference: The Origins and Development of the African Unions Security Culture, 106 Afr. AfF. 253, 272 (2007).

186 See infra Part III.B.3.b on this intervention.

187 OAU Council of Ministers, Doc. CM/Dec. 356 (LXVI) (May 28-31, 1997).

188 Tiyanjana Maluwa, The Constitutive Act of the African Union and Institution-Building in Postcolonial Africa, 16 LEIDEN J. INT’L L. 157, 165 (2003).

189 Kofi Oteng Kufuor, The OAU and the Recognition of Governments in Africa: Analyzing its Practice and Proposals for the Future, 17 AM. U. INT'L L. REV. 369, 395 (2002).

190 Declaration on the Framework for an OAU Response to Unconstitutional Changes of Government, O.A.U. Doc. AHG/Decl.5 (XXXVI) (July 10-12, 2000).

191 A.U. Doc. Central Organ/MEC/AMB/Comm. (XC), ๆ 4 (March 17, 2003).

192 A.U. Doc. PSC/PR/Comm. (XXXIII) - (ii), ף 2 (June 24, 2005).

193 A.U. Doc. PSC/PR/Comm. (XXV), \ 3 \& 4 (Feb. 25, 2005).

194 A.U. Doc. PSC/PR/Comm. (XXX), \ 3 (May 27, 2005). 
However, the current practice is problematic in a two-fold way. In certain respects, it is too farreaching, and in others, it is not inclusive enough. ${ }^{195}$ So far, military coups have been condemned, notwithstanding the legitimacy of the ousted regime. There is, thus, a danger that the mechanism is an instrument to cement the status quo rather than a motor of democratization. ${ }^{196}$ For example, the Mauritanian president Taya, whose legitimacy was questionable at best, was overthrown in a bloodless coup in August 2005. Although the military government announced that it would hold elections within two years and excluded its own participation, the coup was condemned by the African Union and made subject to sanctions. ${ }^{197}$ However, some African politicians voiced critique. The South African ambassador to Mauritania, for example, declared: „[Although] the principle of the AU is not to agree with coups, [...] we believe we shall not have one policy to fit every situation. “198

However, the sanctions against Mauritania were only lifted after the presidential elections in spring 2007. ${ }^{199}$ In two other cases, in which the coup was directed against regimes of doubtful legitimacy, the AU only issued a formal condemnation without imposing further sanctions. The military coup against a corrupt regime in the Ivory Coast in December 1999 was formally condemned, but the transitional government was recognized quite quickly thereafter. ${ }^{200}$ In 2003 , president Kumba Yalla was ousted in Guinea-Bissau after having dissolved the parliament and having adopted some dictatorial decrees. Equally, the AU formally condemned the coup, but did not impose further sanctions. ${ }^{201}$

In contrast, the AU is very reluctant when it comes to other constitutional infringements, like falsifying elections or changing the constitution in order to capture more power or to permit an additional term in office. ${ }^{202}$ However, there may recently have been a step in the right direction. ${ }^{203}$ In Madagaskar, the AU imposed sanctions reacting on a constitutional infringement below the threshold of a military coup. In 2001, Madagascar had a constitutional crisis, when Marc Ravalomanana got the most votes, but failed to get an absolute majority against president Didier Ratsiraka. This result led to demonstrations in the whole country. On mediation of the AU, a commission of the Supreme Court was authorized to count the votes for a second time. According to this vote count, Ravalomanana had gained the absolute majority. However, he declared himself president and captured power by military means. The AU reacted by not recognizing the

195 Williams, supra note 185 , at 274.

196 Djacoba Liva Tehindrazanarivelo, Les sanctions de l'union africaine contre les coups d'Etat et autres changements anticonstitutionnels de gouvernement: potentialités et mesures de renforcement, 12 AFR. Y.B. INT'L L. 255, 280 (2004).

197 A.U. Doc. PSC/PR/Stat. (XXXVI) - (ii) (Aug. 4, 2005).

198 BBC News Online, http://news.bbc.co.uk/1/hi/world/africa/4135350.stm (Aug. 9, 2005).

199 A.U. Doc. PSC/PR/Comm. (LXXVI), I 7 (Apr. 10, 2007).

200 Christof Hartmann, Demokratie als Leitbild der afrikanischen Staatengemeinschaft? Zur Theorie und Praxis demokratischer Schutzklauseln in der Afrikanischen Union, 38 VERFASSUNG UND RECHT IN ÜBERSEE 201, 218 (2005).

201 A.U. Doc. Central Organ/MEC/AMB/Comm. (XCV), I 4 (Sept. 18, 2003).

202 Williams, supra note 185, at 275; Hartmann, supra note 200, at 219-220.

203 Tehindrazanarivelo, supra note 196, at 275. 
new government and requested Mr. Ravalomanana to hold new elections. Furthermore, it suspended Madagascar's participation in the organs of the AU. ${ }^{204}$

\section{(ß) Regional Organizations}

Some regional organizations in Africa have established mechanisms which are similar to the one of the AU. For the ECOWAS, the heads of state and government have declared in the Declaration of Political Principles of the ECOWAS ${ }^{205}$ in 1991 in Abuja:

We believe in the liberty of the individual and in his inalienable right to participate by means of free and democratic processes in the framing of the society in which he lives. We will therefore strive to encourage and promote in each our countries, political pluralism and those representative institutions and guarantees for personal safety and freedom under the law that are our common heritage. ${ }^{206}$

The essence of this declaration was introduced into the ECOWAS treaty ${ }^{207}$ in 1993. Art. 4 lit. $\mathrm{h}$ and $\mathrm{j}$ regard participation in the conduct of government and the promotion of democracy as one of the fundamental principles of the organization. Moreover, art. 58 (2) lit. g offers support in the organization of elections upon the request of a Member State. These principles have been confirmed by the heads of state and government of the ECOWAS in the Protocol on Democracy and Good Governance ${ }^{208}$, which explicitly emphasizes the obligation to hold free, fair and transparent elections:

The following shall be declared as constitutional principles shared by all Member States:

$[\ldots]$

b) Every accession to power must be made through free, fair and transparent elections.

c) Zero tolerance for power obtained or maintained by unconstitutional means.

d) Popular participation in decision-making, strict adherence to democratic principles and decentralization of power at all levels of governance. ${ }^{209}$

The promotion of democracy is also enshrined in art. 4 lit. c of the founding statute of the South African Development Community (SADC) $)^{210}$ as one the fundamental principles. According to art. 5 (1), the objectives of the organization feature, among others, the promotion of common political values "which are transmitted through institutions which are democratic, legitimate and effective” (lit. b) and the consolidation, defense and maintenance of democracy (lit. c). These

204 A.U. Doc. ASS/Dec. 7 (I) (July 10, 2002).

205 Declaration of Political Principles of the ECOWAS, Doc. A/DCL.1/7/91 (Jul. 6, 1991).

206 Id. at 96.

207 Treaty of ECOWAS, Jul. 24, 1993, 35 I.L.M. 660.

208 Protocol on Democracy and Good Governance, Dec. 22, 2001, Doc. A/SP1/12/01.

209 Id. at 11.

210 The Treaty of the Southern African Development Community, Aug. 17, 1992, 32 I.L.M. 116. 
principles are concretized by the SADC Principles and Guidelines Governing Democratic Elections $^{211}$, which were adopted by the SADC summit in Mauritius in August 2004.

\section{(d) Asia}

The continent that is the most reluctant with regard to the promotion of democracy is Asia. There is neither a political organization nor a human rights treaty covering the whole continent. Indeed, there are some sub-regional institutions and treaty mechanisms, which show, however, little enthusiasm towards the idea of electoral legitimacy and democracy. For the Arab region, the Council of the League of Arab States adopted the Arab Charter on Human Rights ${ }^{212}$ in 1994 . However, the Charter does not mention any right to participation in elections or even to democracy.

Certainly, one of the most active political organizations on the Asian continent is the Association of Southeast Asian Nations (ASEAN). ${ }^{213}$ Although ASEAN originally had a strong emphasis on the sovereignty of each member with regard to the form of government, ${ }^{214}$ there have recently been modest trends towards a stronger commitment to democracy. ${ }^{215}$ While the founding documents are mute with regard to the internal organization of the member states, democracy has for the first time been mentioned in the Vientiane Action Program (VAP) of the ASEAN Heads of State and Government. ${ }^{216}$ Under title II of the VAP, the enhancement of democracy is mentioned as one of the goals of ASEAN. Further specifications are lacking, however, a circumstance which suggests that the inclusion of democracy among the principles is nothing but mere rhetoric. ${ }^{217}$ The teleological nature of the applied language is noticeable nonetheless: there is no strict right to democracy, but democracy is enhanced and this enhancement is a goal, not an obligation.

\section{(e) Evaluation}

The analysis of the emergence of different regional commitments to democracy provides an incoherent picture. In Europe and in the Americas, a democracy principle has been established as part of regional customary law. ${ }^{218}$ The human rights treaties, on the one hand, and the founding statutes of the regional political organizations, on the other, contain extensive electoral and democratic guarantees. Furthermore, there are effective sanction mechanisms for states which do

211 SADC Principles and Guidelines Governing Democratic Elections, Aug. 2004, http://www.sadc.int/english/documents/political_affairs/index.php.

212 Arab Charter on Human Rights, Sept. 15, 1994, 18 Hum. Rts. L.J. 151 (1997).

213 Joakim Öjendal, Back to the Future? Regionalism in South-East Asia under unilateral pressure, 80 INT'L AFF. 519, 520 (2004).

214 R. James Ferguson, ASEAN Concord II: Policy Prospects for Participant Regional "Development", 26 CoNTEMPORARY Southeast Asia 393, 396 (2004); Amitav Acharya, Democratisation and the Prospects for Participatory Regionalism in Southeast Asia, 24 ThIRD WORLD QuARTERLY 375, 378 (2003).

215 Id.; Richard Burchill, Regional Integration and the Promotion and Protection of Democracy and Human Rights in Asia: Lessons from ASEAN, 12 ASIAN Y.B. INT'L L. (forthcoming 2007).

216 Vientiane Action Program, Nov. 30, 2004, http://www.aseansec.org/VAP-10th\%20ASEAN\%20Summit.pdf.

217 More optimistic Burchill, supra note 215.

218 See Frowein, supra note 177 on the democracy principle in Europe. See Dinah Shelton, Representative Democracy and Human Rights in the Western Hemisphere, 12 HuM. RTS. L.J. 353 (1991); Dexter S. Boniface, Is There a Democratic Norm in the Americas? An Analysis of the Organization of American States, 8 GLOBAL GOVERNANCE 365 (2002) on the democracy principle in the Americas. 
not meet democratic standards. In particular in Europe, these sanctions do not only concentrate on the existence or absence of elections, but try to implement a more substantive vision of democracy.

For Africa, the evaluation is less clear. The African Union has included democracy as one fundamental objective in its founding statute. Furthermore, the Banjul Charter prescribes a right to participation in the conduct of public affairs. However, although many African states have still to be classified as non-democratic, there is no active institutional promotion of democracy. The established sanction mechanisms exclusively refer to regressions in the process of democratization, which suggests a teleological rather than a strict reading of the established democracy principle.

The least developed commitments to democracy can be found in Asia. There are only modest allusions to democracy in a Plan of Action of the Heads of State and Government of ASEAN which are not sufficient to establish a corresponding democracy principle. This lack of commitment to democracy on the regional level is in line with the reluctance of South East Asian states to enter into treaty obligations concerning political rights at the universal level.

\section{Democracy and the Use of Force}

The most attention in the literature on the emergence of a democracy principle has been absorbed by military interventions in the name of democracy. Such interventions could be an indicator for the emergence of a customary principle with regard to democracy. The following analysis will concentrate on five possible precedents: on the one hand, the unilateral military interventions of the United States in Grenada, Panama and Iraq (a); on the other hand, the interventions in Haiti and Sierra Leone, which were approved by the U.N. Security Council (b).

\section{(a) Unilateral Interventions in Grenada, Panama and Iraq}

Reacting to a coup d'état against the government of Maurice Bishop, U.S. troops invaded Grenada on October 25, 1983 with the support of neighboring Caribbean states. Three days after the invasion, the U.S. military succeeded in overthrowing the military council which had come to power after the coup d'état. In the subsequent debate among legal scholars on the legality of the U.S. intervention, some authors put forward the restoration of democracy as a legal justification. ${ }^{219}$ However, there are several reasons against such an interpretation: First, Bishop himself attained power not by democratic means, but by a coup d'état in $1979 .{ }^{220}$ Second, restoration of democracy was not put forward by the U.S. administration in its attempt to justify the interven-

\footnotetext{
219 William Michael Reisman, Coercion and Self-Determination: Construing Charter Article 2(4), 78 Am. J. INT'L L. 642 (1984); FERNANDO R. TESÓN, HUMANITARIAN INTERVENTION: AN INQUIRY INTO LAW AND MORALITY 258 (3d ed. 2005). See also ROTH, supra note 130, at 309 (considering the Grenada invasion to be a positive precedent).

220 Louise Doswald-Beck, The Legality of the United States Intervention in Grenada, 24 INDIAN J. INT'L L. 200, 201 (1984).
} 
tion. ${ }^{221}$ Only the subsequent evaluation of the intervention by academic commentators is barely sufficient as a basis for an emerging practice or opinio iuris. ${ }^{222}$ Finally and most importantly, the U.N. General Assembly condemned the intervention as illegal with an overwhelming majority (108-9-27). ${ }^{223}$ Certainly, resolutions of the U.N. General Assembly are not directly binding. However, they are expression of the opinio iuris of the international community that the intervention cannot be regarded as a precedent for the emergence of a right to a pro-democratic intervention. $^{224}$

A second potential precedent for democracy as a title for intervention is the U.S. invasion in Panama in 1989. ${ }^{225}$ On December 20, 1989, the U.S. army invaded Panama in order to overthrow the regime of Manuel Noriega and to capture the head of state himself. Among other reasons, like the protection of U.S. citizens, the combat of drug trafficking, and the implementation of the Panama Canal treaties, President George Bush Sr. explicitly mentioned the protection of democracy as justification for the intervention. ${ }^{226}$ However, the U.N. General Assembly again condemned the intervention with a clear majority (75-20-40) as illegal. ${ }^{227}$ Therefore, the intervention in Panama may not serve as precedent for the emergence of a democracy principle in international law either. ${ }^{228}$

The most recent case in which regime change was discussed as justification for the beginning of a war was the invasion of the U.S. and the "Coalition of the Willing” in Iraq in March 2003. ${ }^{229}$ In

221 Oscar Schachter, The Legality of Pro-Democratic Invasion, 78 AM. J. INT'L L. 645, 648 (1984); Michael Byers \& Simon Chesterman, "You, the People": pro-democratic intervention in international law, in DEMOCRATIC GOVERNANCE AND INTERNATIONAL LAW 259, 273 (Gregory H. Fox \& Brad R. Roth eds., 2000). Wouters, De Meester \& Ryngaert, supra note 120, at 169.

223 G.A. Res. 38/7, U.N. Doc. A/RES/38/7 (Nov. 2, 1983): „Deeply deplores the armed intervention in Grenada, which constitutes a flagrant violation of international law and of the independence, sovereignty and territorial integrity of that state." (emphasis in the original).

224 SCOTT DAVIDSON, GRENADA: A Study in Politics AND the Limits of InTERnATIONAL LAw 147 (1987); Byers \& Chesterman, supra note 221, at 274.

225 Abraham D. Sofaer, The Legality of the United States Action in Panama, 29 CoL. J. TrAnSNAT'L L. 281, 28890 (1991); William Michael Reisman, Humanitarian Intervention and Fledging Democracies, 19 FORDHAM INT'L L. J. 794, 800 (1995); TESÓN, supra note 219, at 269. But see also Anthony D'Amato, The Invasion of Panama Was a Lawful Response to Tyranny, 84 AM. J. INT'L L. 516, 519 (1990) (referring to the human rights violations of the Noriega regime and explicitly rejecting the possibility of a pro-democratic intervention).

226 President George Bush, Address to the Nation Announcing United States Military Action in Panama, If 2 (Dec. 20, 1989), http://www.presidency.ucsb.edu/ws/print.php?pid=17965.

227 G.A. Res. 44/240, U.N. Doc. A/RES/44/240 (Dec. 29, 1989): „Strongly deplores the intervention in Panama by the armed forces of the United States of America, which constitutes a flagrant violation of international law and of the independence, sovereignty and territorial integrity of states." (emphasis in the original).

228 Ved P. Nanda, The Validity of United States Intervention in Panama under International Law, 84 AM. J. INT'L L. 494, 500 (1990); John Quigley, The Legality of the United States Invasion of Panama, 15 YALE J. INT'L L. 276, 303-6 (1990); Oscar Schachter, Is There a Right to Overthrow an Illegitimate Regime?, in LE DROIT INTERNATIONAL AU SERVICE DE LA PAIX, DE LA JUSTICE ET DU DEVELOPPEMENT. MÉLANGES MiCHEL VIRALly 423, 428 (Jean Boulouis \& René-Jean Dupuy eds., 1991); Louis Henkin, The Invasion of Panama Under International Law: A Gross Violation, 29 CoL. J. TRANSNAT'L L. 293, 298 (1991); Sarah A. Rumage, Panama and the Myth of Humanitarian Intervention in U.S. Foreign Policy: Neither Legal Nor Moral, Neither Just Nor Right, 10 ARIZONA J. INT'L \& COMP. L. 1, 54-57 (1993); IAN BROWNLIE, THE RULE OF LAW IN INTERNATIONAL AFFAIRS 59-62 (1998); Byers \& Chesterman, supra note 221, at 275

229 See Davis Brown, Iraq and the 800-Pound-Gorilla Revisited: Good and Bad Faith, and Humanitarian Intervention, 28 HASTINGS INT'L \& COMP. L. REV. 1 (2004); Robert F. Turner, Operation Iraqi Freedom: Legal and Policy Considerations, 27 HARV. J. L. \& PUBL. PoL'y 765, 778 (2004); TESÓN, supra note 219, at 392 
his State of the Union address on January 28, 2003, President George W. Bush declared: „And tonight I have a message for the brave and oppressed people of Iraq: Your enemy is not surrounding your country - your enemy is ruling your country. And the day he and his regime are removed from power will be the day of your liberation.“ ${ }^{230}$

Among the political considerations, which finally led to the war, Iraq's democratization was a major reason. It is telling, however, that neither the U.S. nor Great Britain mentioned regime change as title for intervention in their official legal justifications of the Iraq war. ${ }^{231}$ The intervention was instead justified by a corresponding interpretation of resolutions $678^{232}, 687^{233}$ and $1441^{234}$ of the U.N. Security Council. ${ }^{235}$ Furthermore, the intervention was condemned by a considerable part of the international community. Among the opponents were states like Belgium, Canada, China, Germany, France, New Zealand, Russia, Sweden and Switzerland. Thus, the Iraq war can equally not be regarded as precedent for the emergence of an international democracy principle. $^{236}$

\section{(b) Collective Interventions in Haiti and Sierra Leone}

In the search for precedents for the emergence of a democracy principle in international law, collective interventions, which have been authorized by an international institution, might be more promising indices than the unilateral interventions we have examined so far. In this respect, many legal scholars qualify the intervention in Haiti in 1991, which had been authorized by the U.N. Security Council, as a paradigmatic precedent. ${ }^{237}$ In 1990, Jean-Bertrand Aristide was

(considering the democratization of Iraq as the primary justification if the war). However, all of these authors emphasize the human rights violations of Saddam Hussein's regime. Thus, the totalitarian form of government alone is implicitly not regarded as sufficient to justify an intervention.

230 George W. Bush, President Delivers „State of the Union“, http://www.whitehouse.gov/news/releases/2003/01/print/20030128-19.html.

231 Dino Kritsiotis, Arguments of Mass Confusion, 15 EUR. J. INT’L L. 233, 273-74 (2004).

232 S.C. Res. 678, U.N. Doc. S/RES/678 (Nov. 29, 1990).

233 S.C. Res. 687, U.N. Doc. S/RES/687 (Apr. 3, 1991).

234 S.C. Res. 1441, U.N. Doc. S/RES/1441 (Nov. 8, 2002).

235 Compare on the one hand Letter dated 20 March 2003 from the Permanent Representative of the United States of America to the United Nations addressed to the President of the Security Council, U.N. Doc. S/2003/351, and on the other hand Statement by the Attorney General, Lord Goldsmith, in Answer to a Parliamentary Question (March 18, 2003), http://www.fco.gov.uk/servlet/Front?pagename=OpenMarket/Xcelerate/ShowPage\&c=Page\&cid=10070293 91629\&a=KArticle\&aid=1047661460790.

236 Richard A. Falk, What Future for the UN Charter System of War Prevention?, 97 AM. J. INT'L L. 590, 597 (2003); Mary Ellen O'Connell, La doctrine américaine et l'intervention en Iraq, 49 ANNUAIRE FRANÇAIS DE DROIT INTERNATIONAL 3, 12-14 (2003); Michael Bothe, Der Irak-Krieg und das völkerrechtliche Gewaltverbot, 41 ARCHIV DES VÖLKERRECHTS 255, 258 (2003); Andreas Paulus, The War against Iraq and the Future of International Law: Hegemony or Pluralism?, 25 MiCH. J. INT'L L. 691, 711 (2004); Jason Pedigo, Rogue States, Weapons of Mass Destruction, and Terrorism: Was Security Council Approval Necessary for the Invasion of Iraq? 32 GA. J. INT'L \& COMP. L. 199, 223 (2004).

237 Escudero Espinosa, supra note 99, at 375; Morton H. Halperin \& Kristen Lomasney, Guaranteeing Democracy: A review of the record, 9.2 J. DEM. 134, 138 (1998); William Michael Reisman, Sovereignty and human rights in contemporary international law, in DEMOCRATIC GOVERNANCE AND INTERNATIONAL LAW 239, 248 (Gregory H. Fox \& Brad R. Roth eds., 2000); Kokoroko, supra note 120, at 52; TESÓN, supra note 219, at 307-17. 
elected as Haitian president with $67 \%$ of the votes. ${ }^{238}$ The elections were monitored by the United Nations $^{239}$ and the OAS $^{240}$ upon Haiti's request. On September 30, 1991, Aristide was overthrown by the military. After remaining passive in the beginning, the U.N. Security Council adopted Resolution 841 in June 1993, which imposed economic sanctions on Haiti. ${ }^{241}$ Because of the sanctions, the military regime in Haiti agreed to conclude the so-called Governors Islands agreement, in which it conceded to bring Aristide back into power. However, the implementation of the agreement failed when members of the junta exercised force against partisans of Aristide in autumn 1993. The Security Council again adopted economic sanctions ${ }^{242}$ and set up a naval blockade ${ }^{243}$. On July 31, 1994, it finally adopted Resolution 940, which permitted all U.N. member states to use force to reinstall the legitimate government in Haiti. ${ }^{244}$ On September 18, the former U.S. President Jimmy Carter convinced the junta - with the support of Senator Sam Nunn and General Colin Powell - to cede power to Aristide and to leave the country, just hours before a multinational troop under U.S. leadership was going to land in Haiti.

Several authors deny the intervention in Haiti the character as a precedent for a collective prodemocratic intervention. Some argue that the Security Council primarily addresses the protection of peace and security in the region. ${ }^{245}$ However, this reference has to be seen in the context of the new activism of the Security Council in the 1990s. In a series of resolutions, the Security Council interpreted the notion of peace and security in Chapter VII of the U.N. Charter broadly. Peace and security was not only understood as the absence of the use of military force. It also referred to internal crises in order to cover catastrophes such as in Somalia or Rwanda. ${ }^{246}$ While formally respecting the text of the Charter, the Security Council has, with overwhelming support of the legal literature, ${ }^{247}$ broadened its competences in order to cope with the changed circumstances after the end of the Cold War. Thus, despite the reference to peace and security in the region, Resolution 940 was clearly focused on the restoration of the internal order in Haiti. ${ }^{248}$

\footnotetext{
238 See Christina M. Cerna, The Case of Haiti before the Organization of American States, 86 AM. Soc. INT'L L. PROC. 378 (1992) for a detailed account of the events.

239 G.A. Res. 45/2, U.N. Doc. A/RES/45/2 (Oct. 10, 1990).

240 O.A.S. Doc. OEA/Ser.G/CP/RES.537, Doc. 805 (Feb. 23, 1990).

241 S.C. Res. 841, U.N. Doc. S/RES/841 (June 16, 1993).

242 S.C. Res. 873, U.N. Doc. S/RES/873 (Oct. 13, 1993).

243 S.C. Res. 875, U.N. Doc. S/RES/875 (Oct. 15, 1993).

244 S.C. Res. 940, U.N. Doc. S/RES/940 (July 31, 1994).

245 BARDO FASSBENDER, Un SECURITY COUNCIL REForm AND THE Right of Veto. A CONSTITUTIONAL PERSPECTIVE 218 (1998); Byers \& Chesterman, supra note 221, at 287.

246 See Hermann-Josef Blanke, Menschenrechte als völkerrechtliche Interventionstitel, 36 ARCHIV DES VÖLKERRECHTS 257, 278-80 (1998).

247 Richard B. Lillich, The Role of the UN Security Council in Protecting Human Rights in Crisis Situations: UN Humanitarian Intervention in the Post Cold War World, 3 TulanE J. INT'L \& COMP. L. 1 (1995); Blanke, supra note 246; Antonio Cassese, Ex iniuria ius oritur: Are We Moving towards International Legitimation of Forcible Humanitarian Countermeasures in the World Community?, 10 EUR. J. INT'L L. 23, 26 (1999); TESÓN, supra note 219.

248 Louis E. Fielding, Taking the Next Step in the Development of New Human Rights: The Emerging Right of Humanitarian Assistance to Restore Democracy, 5 DukE J. CoMP. \& INT'L L. 329, 366-69 (1995); Douglas Lee Donoho, Evolution or Expediency: the United Nations Response to the Disruption of Democracy, 29 CORNELL INT'L L.J. 329, 362-64 (1996); Mary Ellen O'Connell, Regulating the Use of Force in the 21st Century: the Continuing Importance of State Autonomy, 36 COL. J. TRANSNAT'L L. 473, 487 (1997); TESÓN, supra note 219 , at 312 .
} 
Some scholars doubted the competence of the U.N. Security Council to authorize an intervention in order to restore democracy. ${ }^{249}$ Others argued that the case of Haiti could not be generalized because of the specific regional context. ${ }^{250}$ Further commentators refer to the general human rights situation in Haiti ${ }^{251}$ or the violation of the Governors Islands Agreement as a justification for the Security Council resolution. ${ }^{252}$ However, these objections cannot call into question that the restoration of democracy was the explicit objective of resolution 940. This is, on the one hand, expressed in the preamble: "Reaffirming that the goal of the international community remains the restoration of democracy in Haiti and the prompt return of the legitimately elected President, Jean-Bertrand Aristide, within the framework of the Governors Island Agreement”253.

On the other hand, the support of the legitimate government of Haiti also plays an important role in the operative part:

1. Welcomes the report of the Secretary-General of 15 July 1994 (S/1994/828) and takes note of his support for action under Chapter VII of the Charter of the United Nations in order to assist the legitimate Government of Haiti in the maintenance of public order;

$[\ldots]$

4. Acting under Chapter VII of the Charter of the United Nations, authorizes Member States to form a multinational force under unified command and control and, in this framework, to use all necessary means to facilitate the departure from Haiti of the military leadership, consistent with the Governors Island Agreement, the prompt return of the legitimately elected President and the restoration of the legitimate authorities of the Government of Haiti, and to establish and maintain a secure and stable environment that will permit implementation of the Governors Island Agreement, on the understanding that the cost of implementing this temporary operation will be borne by the participating Member States ${ }^{254}$

Although the preamble also refers to the human rights situation in Haiti, ${ }^{255}$ the latter does not have the same importance as the restoration of the legitimate order as becomes apparent in the operative part. ${ }^{256}$ Furthermore, the reference to the Governors Islands Agreement is not essential, but only supportive. It has to be taken into account that it was the main purpose of the agreement

249 Michael J. Glennon, Sovereignty and Community after Haiti: Rethinking the Collective Use of Force, 89 AM. J. INT'L L. 70 (1995); Donoho, supra note 248; Byers \& Chesterman, supra note 221, at 290-92.

250 Olivier Corten, La résolution 940 du Conseil de sécurité autorisant une intervention militaire en Haiti: L'émergence d'un principe de légitimité démocratique en droit international?, 6 EUR. J. INT'L L. 116, 129 (1995); Julia Leininger, Democracy and UN Peace-Keeping - Conflict Resolution through State-Building and Democracy Promotion in Haiti, 10 MAX PlancK YeARBOOK OF UnITED NATIONs LAW 465, 489 (2006).

251 Lillich, supra note 247, at 10. See KARIN VON HIPPEL, DEMOCRACY BY FORCE: Us MILITARY INTERVENTION IN THE POST-COLD-WAR WORLD 98 (2000) with regard to the human rights violations of the régime Cedras.

252 Corten, supra note 250, at 126.

253 S.C. Res. 940, supra note 244.

254 Id. (emphasis added).

255 Id. (,Gravely concerned by the significant further deterioration of the humanitarian situation in Haiti, in particular the continuing escalation by the illegal de facto regime of systematic violations of civil liberties, the desperate plight of Haitian refugees and the recent expulsion of the staff of the International Civilian Mission (MICIVIH), which was condemned in its Presidential statement of July 12, 1994 (S/PRST/1994/32)“).

256 See equally Corten, supra note 250, at 127 (emphasizing that Haiti cannot be compared to Bosnia, Somalia or Rwanda concerning the intensity and the gravity of the atrocities). 
to reinstall the preceding order. It is not plausible why the Security Council should have had the competence to implement an agreement between a de facto regime and a de jure government, independent of its content. Even if it was the purpose of the resolution to implement the Governors Islands agreement, this was just because of the content of the latter. The normative concerns with regard to the competence of the Security Council, finally, are irrelevant for the examination of a practice and an opinio iuris on the emergence of a democracy principle. ${ }^{257}$ Only the reception of the intervention by the international community is of importance in this respect.

Nevertheless, the scope of the Haiti precedent is limited. ${ }^{258}$ The intervention addressed the restoration of a disrupted, but previously already existing, constitutional order. It can, thus, not be regarded as an indicator for the emergence of a universal democracy or legitimacy principle. However, it fits into the patterns we have already observed in the context of the resolutions of the General Assembly. If the democracy principle in international law is teleological and process-oriented, then countries are indeed not obliged to turn into a democracy from one day to the other. Teleology, however, prohibits setbacks in the process of democratization. If collective interventions, such as the intervention in Haiti, occur after coups d'état against elected governments, this practice confirms the principle of democratic teleology.

In a similar line is the second precedent, the intervention of Nigeria, or of ECOWAS respectively, in Sierra Leone. In the latter, a country plagued by Civil War, the parties of the conflict agreed in 1996 to hold presidential elections. In these elections, Ahmad Tejan Kabbah was elected for president. As the Rebel Unity Front (RUF) did not only lose the elections, but was also weakened on the battlefield, the parties concluded the Abidjan Accord on September 30, 1996, in which they agreed on an immediate ceasefire and the disarmament of the combatants. This agreement did, however, not contribute to a détente. On the contrary, on May 25, 1997, the president of Sierra Leone was overthrown. This prompted the Nigerian troops of the ECOWAS Monitoring Group (ECOMOG) to intervene. In June 1997, the Nigerian forces invaded Sierra Leone and helped to reinstall Kabbah as president in March 1998. The U.N. Security Council did not approve the intervention until afterwards. In October 1997, the Security Council expressed

257 This is equally valid for the critique on the democratic intentions of the intervening states. See Richard A. Falk, The Haiti Intervention: A Dangerous World Order Precedent for the United Nations, 36 HARV. INT'L L. J. 314, 353 (1995); Anne Orford, Muscular Humanitarianism: Reading the Narratives of the New Interventionism, 10 EUR. J. INT’L L. 679, 701 (1999) (raising such critique).

258 ROTH, supra note 130, at 386; James Crawford, Democracy in international law - a reprise, in DEMOCRATIC GOVERNANCE IN INTERNATIONAL LAW 114, 117 (Gregory H. Fox \& Brad R. Roth eds., 2000). But cf. also John C. Pierce, The Haitian Crisis and the Future of Collective Enforcement of Democratic Governance, 27 LAW \& POL'Y INT'L Bus. 477-512 (1996); Fernando R. Tesón, Collective Humanitarian Intervention, 17 MICH. J. INT'L L. 323, 355 (1996) (regarding the Haiti intervention as a precedent for the emergence of a fullscale right to democratic intervention). 
its support for the ECOWAS action, ${ }^{259}$ and on March 16, 1998 it welcomed the return of president Kabbah into office. ${ }^{260}$

The legal literature discusses different justifications for the ECOMOG intervention: they range from a pro-democratic intervention, ${ }^{261}$ via a humanitarian intervention, ${ }^{262}$ to an intervention on invitation by the de jure government. ${ }^{263}$ Some authors have raised doubts concerning the democratic intention of the intervening states, as Nigeria, being the leader of the intervention, was itself ruled by an autocratic government. ${ }^{264}$ However, in order to evaluate the character of the intervention as a precedent, the reception by the international community is more important than the intention of the intervening parties, because the former is the indication for the existence of an opinio iuris. The Security Council resolutions on Sierra Leone emphasize the restoration of the democratic order. Resolution 1132 asks the military junta to restore the democratic order, ${ }^{265}$ while resolution 1156 welcomes the return to democracy. ${ }^{266}$ Therefore, the case of Sierra Leone confirms the patterns we have observed with regard to Haiti. The international community regards the overthrow of an elected government as violation of international law, ${ }^{267}$ which confirms the existence of a principle of democratic teleology in international law.

\section{Résumé}

International law does not provide for a strict right to democratic governance. The international documents and the corresponding practice rather emphasize the process-oriented character of democratization. Democracy is perceived as a teleological principle. ${ }^{268}$ States and societies are

259 S.C. Res. 1132, S/RES/1132 (Oct. 8, 1997) („Expresses its strong support for the efforts of the ECOWAS Committee to resolve the crisis in Sierra Leone and encourages it to continue to work for the peaceful restoration of the constitutional order, including through the resumption of negotiations“) (emphasis in the original).

260 S.C. Res. 1156, S/RES/1156 (March 16, 1998) („Welcomes the return to Sierra Leone of its democratically elected president on 10 March 1998“) (emphasis in the original).

261 Jeremy Levitt, Humanitarian Intervention by Regional Actors in Internal Conflicts: The Cases of ECOWAS in Liberia and Sierra Leone, 12 TEMPLE INT'L \& COMP. L.J. 333, 370 (1998); Valentina Grado, Il ristabilimento della democrazia in Sierra Leone, 83 RIV. DIR. INT. 361, 395 (2000) (basing her argumentation, however, rather on the defense of the internal dimension of the right to self-determination than on an explicit defense of democracy).

262 Lee F. Berger, State Practice Evidence of the Humanitarian Intervention Doctrine: The ECOWAS Intervention in Sierra Leone, 11 IndiANA INT'L \& COMP. L. REV. 605, 626-32 (2001); Marco Gestri, ECOWAS Operations in Liberia and Sierra Leone: Amnesty for Past Unlawful Acts or Progress toward Future Rules?, in Redefining Sovereignty. The Use of Force After the Cold WAR 211, 247 (Michael Bothe, Mary Ellen O'Connell \& Natalino Ronzitti eds., 2005).

263 Karsten Nowrot \& Emily W. Schabacker, The Use of Force to Restore Democracy: International Legal Implications of the ECOWAS Intervention in Sierra Leone, 14 AM. U. INT'L L. REV. 321, 401-2 (1998); Matthias Goldmann, Sierra Leone: African Solutions to African Problems?, 9 MAX PlAnCK YEARBOOK OF UNITED NATIONS LAW 457, 471-72 (2005).

264 Byers \& Chesterman, supra note 221, at 290; Goldmann, supra note 263, at 473.

265 S.C. Res. 1132, supra note. 259: „Demands that the military junta take immediate steps to relinquish power in Sierra Leone and make way for the restoration of the democratically-elected Government and a return to constitutional order" (emphasis in the original).

266 See supra note 260.

267 ROTH, supra note 130, at 393.

268 From a theoretical perspective, one might object to the normative interpretation proposed in this contribution that it contradicts the binary character of law. According to Niklas Luhmann, law only knows the distinction between legal and illegal, but no differentiation of more or less; see NIKLAS LUHMANN, LAW AS A SOCIAL 
thus obliged to develop towards democracy. In this context, democratization has two directions of impact. ${ }^{269}$ On the one hand, it is directed against democratic erosion, regressions in the process of democratization. These can be obvious cases, such as military coups. This is underlined by the practice of the U.N. Security Council, which endorsed military action after elected governments had been overthrown in Haiti and Sierra Leone. In contrast, the sole illegitimacy of a regime has never been a reason for the Security Council to take any action.

But regressions are not limited to coups d'état. They also include other setbacks in the process of democratization and consolidation of democracy, such as increasing centralizations of power with the head of the executive or the cession of political control to the military. Examples are the autogolpe of Alberto Fujimori in Peru in 1992 or the 'constitutional referendum' of Alexander Lukashenko in Belarus in $1995 .{ }^{270}$ This is emphasized, in particular, by the sanction mechanisms of the OAS and the AU. Both are meant to impose sanctions not only for military coups, but also for other measures intended to erode democracy. The regional practice is more reluctant in cases in which formal elections have been held, but if these have been falsified by undue influence. In theory, however, such cases equally constitute setbacks in the process of democratization, which run counter to the principle of democratic teleology.

On the other hand, democratization is not only concerned with avoiding setbacks and regressions. There is also a second aspect, which concerns the positive and active development towards democracy and, once the transition has occurred, towards democratic consolidation. As we lack an ideal type of democracy as well as an ideal way of democratization, however, this second aspect cannot be turned into a concrete obligation to perform a specific action. Governments have a certain margin of appreciation in this respect, and we can only classify those strategies as illegal which are clearly defective. In order to determine such strategies, we may adopt the same classification which I have proposed in the context of the principle of self-determination. ${ }^{271}$ According to this proposal, regimes which are not self-enriching, but development-oriented, and which observe core human rights have to be regarded as legal and legitimate. Legitimacy under international law does therefore not necessarily require a state to be democratic.

SYSTEM 93 (2004). However, this binary distinction only applies to concrete decisions. On the abstract level, one might distinguish between rules and principles. See already Niels Petersen, Customary Law without Custom? - Rules, Principles, and the Role of State Practice in International Norm Creation, 23 AM. U. INT'L L. REV. (forthcoming 2008) (justifying this distinction and citing further references). Only the former contain binary codes of conduct, while the latter are principles of optimization, which by definition already know the distinction of more and less; see ROBERT ALEXY, A THEORY OF CONSTITUTIONAL RIGHTS 47-48 (2002). The principle of democratic teleology has thus to be qualified as legal principle in the latter sense.

270 See Laurence Whitehead, The Consolidation of Fragile Democracies: A Discussion with Illustrations, in Democracy in the Americas: Stopping the Pendulum 76-95 (Robert A. Pastor ed., 1989) (referring to further examples from Latin America). 


\section{Conclusion}

Nearly two decades after the fall of the Berlin Wall, the democracy euphoria of scholars in international relations and international law cooled down considerably. Democracy is not the cure-all it was widely considered to be. Moreover, the third wave of democratization ${ }^{272}$ was weaker in the end than many observers had foreseen in the beginning of the 1990s. Even though there is nearly a consensus in philosophy and political sciences that, in the long run, there can be no suitable alternative to democracy as a form of state, we have seen that democratization is not purely a simple change of the political status. Instead, it is a long-term and complex social process and its preconditions are still very much under discussion in social science research.

This contribution has attempted to meet these concerns by framing democracy as a teleological principle. In international law, democracy is neither an absolute right nor a strict obligation. The identified norm rather focuses on the process-like character of democratization. States are merely obliged to develop towards democracy. This understanding of the democratic principle in international law can also better be reconciled with the existing legal documents. These do not use a prescriptive, but rather a process-oriented language. The concrete development of the process of democratization is, to a large extent, part of the appreciation of each state.

Because of the binary character of legal norms, lawyers like to have clear standards. Karl-Heinz Ladeur once offered a metaphor in which he compared the law to a blind man who uses a stick in order to scan the ground on which he is walking. ${ }^{273}$ In this process, he always makes the distinction between a stable and an unstable ground. In so doing, he creates a system of orientation without being able to evaluate the world in its whole complexity. Lawyers act in a similar fashion when they merely ask about the legality or the illegality of certain actions or conditions. In this context, they need standards that allow them to make clear binary distinctions. The stricter legal standards are, the higher the determinacy of legal norms is. Against this background, the principle of democratic teleology does not deserve very good marks. Whether a state has held elections or not is a question of fact that can be answered quite easily. ${ }^{274}$ In contrast, the question whether a government acts in the interest of its population requires difficult normative valuations.

However, strict normative standards do not always take into account the complexity of reality. Martti Koskenniemi has shown in his dissertation that the determinacy of international legal norms is always subject to a necessary structural deficit. ${ }^{275}$ According to Koskenniemi, absolute

272 HUNTINGTON, supra note 32.

273 KARL-HEINZ LADEUR, THE THEORY OF AutOPOIESIS AS AN APPROACH TO A BETTER UNDERSTANDING OF Postmodern LaW: From the Hierarchy of Norms to the Heterarchy of CHANGing Patterns of LeGAL INTER-RELATIONSHIPS 12 (1999).

274 See Guillermo O'Donnell, Illusions About Consolidation, 7.2 J. DEM. 34,45 (1996); Marks, supra note 10, at 87 (indicating that this is probably the reason, why the discussion on the right to democratic governance is dominated by a static concept of democracy, which is only focused on elections). It has to be remarked, however, that this question is not totally free of normative evaluations either, as the judgment whether elections have been free and fair requires some assessment.

275 MARTTI KOSKENNIEMI, From Apology to Utopia. The Structure of the International Legal ARGUMENT 590-96 (2005). 
legal standards are always either over- or under-inclusive. ${ }^{276}$ International law thus suffers from an inherent tension between determinacy and justice. The more determinate legal standards are, the less apt they are to take into account the complexity of reality; and the more they adjust to complexity, the less determinate they are. ${ }^{277}$ International law, in particular, depending in its effectiveness on the acceptance of the actors it addresses, cannot afford to impose strict standards if the evaluation of different circumstances and strategies is as diverse as in the context of global democratization.

Francis Fukuyama's diagnosis of "the end of history”278 has been premature. Democracy still has a long way to go and this is reflected by the present state of international law. In the legal debate of the 1990s, even those authors favourable of the democratic entitlement did not claim the unconditional establishment of a right to democratic governance. ${ }^{279}$ Instead, most of them have identified a democratic trend ${ }^{280}$ or, most famously, an emerging right to democratic governance. $^{281}$ The preceding analysis suggests reformulating this thesis: international law contains a teleological democracy principle, a right to the emergence of democratic governance.

$276 \quad$ Id. at 591.

277 But see also id. (arguing that the tension is always solved to the detriment of determinacy because even standards which seem to be absolute may be softened through interpretation). FUKUYAMA, supra note 2 .

279 Gregory H. Fox \& Brad R. Roth, The spread of liberal democracy and its implications for international law, in Democratic Governance And InTERnational Law 1, 13 (Gregory H. Fox \& Brad R. Roth eds., 2000). Rich, supra note 120 , at 33 . 